\title{
EL CASTILLO REAL DE LLEIDA EN ÉPOCA MEDIEVAL
}

\author{
FRANCESCA ESPAÑOL BERTRAN \\ Universidad de Barcelona
}

\begin{abstract}
SUMARIO
I. Introducción.- II. El castillo real durante los siglos XII, XIII, XIV y $\mathrm{XV}$. Datos documentales.- III. Las descripciones antiguas del edificio y la serie de mapas militares de 1796.- IV. Estado del castillo de Lleida en el siglo XVIII. Evaluación de su fábrica a partir de las descripciones y los planos de 1796.- V. El castillo real de Lleida en época medieval: proceso de la obra.- VI. La Zuda de Lleida en el contexto de los castillos reales de la Corona de Aragón.
\end{abstract}

\section{INTRODUCCIÓN}

En 1812, durante la guerra de la Independencia, una explosión destruyó parcialmente el castillo real de Lleida situado sobre la Roca Sobirana, <Fig. $1>$ fortaleza de origen musulmán que como en otros lugares recibía el apelativo de $\mathrm{Zuda}^{1}$. Formando un todo con la catedral

'El contenido de este trabajo se presentó en la Semana de Estudios Medievales de Aguilar de Campoo del año 1992.

Conviene advertir que algunas de las ilustraciones del trabajo están intercaladas a lo largo del texto, mientras que las restantes se hallan reunidas en un cuadernillo al final del estudio. Pese a ello, la numeración de todas ellas es correlativa.

Sobre la denominación Zuda aplicada a las residencias fortificadas de los príncipes de Taifas: L. TORRES BALBÁS, "Bab Al-Sudda" y las Zudas de la España Oriental, "Al-Andalus", XVII (1952), pp. 165-175. Recordemos que, además de Lleida, tambien se habla de Zuda en

"Anuario de Estudios Medievales", 26 (1996) 
erigida durante el siglo XIII, hacia 1707 tras caer la ciudad ante el ejercito borbónico ${ }^{2}$, había sido destinada a usos militares <Fig. $2>$. Su estructura medieval, sin embargo, se conservaba optimamente. La explosión de 1812 fue el punto de partida de un inexorable proceso de degradación <Fig. 3> que culminó cuando el edificio fue víctima de otra voladura el año 1936. Tras ésta, las ruinas del emplazamiento árabe y más tarde (desde finales del siglo XII) castillo real cristiano, han sobrevivido penosamente ante la general indiferencia.

Aunque en $1986^{3}$ se llevó a cabo una campaña de excavación reanudada recientemente, determinar con seguridad la estructura primitiva de un edificio que había sobrevivido sin alteraciones remarcables en su fábrica hasta el siglo XIX ${ }^{4}$, no resulta fácil. A este hecho se añade, además, un nuevo problema: la contradicción en la que incurren dos fuentes historiográficas del siglo XVIII al describirlo. Se trata del Fragmento histórico de la catedral, iglesias y ciudad de Lérida de Pere Joan Finestres ${ }^{5}$

Balaguer, Tortosa, Zaragoza, Huesca, Calatayud, Tarazona, Barbastro..,.

${ }^{2}$ Existe una abundante literatura sobre este punto. Remitimos a los trabajos más recientes sobre la historia monumental de la Roca Sobirana, tras ser destinada en su totalidad a usos militares. Véase: F. VILA, Desfeta i recuperació de la Seu Vella, en: "Congrés de la Seu Vella de Lleida". Actes, Lleida, 1991, pp. 357-367. También los trabajos de J.M. MuÑOZ y A. Ros I PERDRIX en el mismo volumen de actas.

${ }^{3}$ La campaña realizada de junio a diciembre de 1986 (sobre ella véase el trabajo de J. Markalain citado en la nota que sigue) ha sido retomada en 1992. Sobre las intervenciones arqueológicas en la ciudad, entre ellas la que tiene como marco el ambito del castillo: A. Loriente, A. Oliver, A. PÉrez, El municipium de Ilerda y Medina Larida. Diez años de arqueología urbana en Lleida, "Arqueología", 149 (1993), pp. 16-25.

${ }^{4} \mathrm{~J}$. Puig Y Cadafalch, A. Falguera y Sivilla, J. Goday y CaSals, L'arquitectura romànica a Catalunya, III-2, Barcelona, 1918 (2da. ed., Barcelona, 1983), pp. 643-644. LL MONREAL, M. DE RIQUER, Els castells medievals de Catalunya, III, Barcelona, 1965. F. LARA PEINADO, La Zuda de Lérida. Estudio artístico histórico, "Ilerda", (en lo sucesivo "I"), XXXIII (1971); J. Lladonosa, La Suda. Parròquia de la Seu de Lleida, Lleida, 1979. Los artículos de Lara y Lladonosa han sido recogidos, con otros, en: Els Castells Catalans, VI-II, Barcelona, 1979, pp. 833-868, 910-916. F.ESPAÑ OL BERTRAN, Plànols $i$ perfils del quarter del castell de La Suda de Lleida, en Cataluña Medieval (catálogo de exposición), Barcelona, 1992, pp. 232235. J. MARKALAIN I TORRES, La Suda de Lleida. Resum de les actuacions arqueològiques, en: Lleida, la ciutat dels dos turons, Lleida, 1992, pp. 67-74.

${ }^{5}$ P.J. FINESTRES, Fragmento Histórico de la catedral, iglesias y ciudad de Lérido (fragmentos de la obra en: J. PASQUAL, Sacrae Antiquitatis Cathalonia Monumenta, II, fol. 140 y fol. 201 v.), Barcelona, Biblioteca de Catalunya, Ms. 729. El texto más completo de esta obra se conserva en Lleida: P.J.FINESTRES, Fragmento Histórico de la catedral, iglesias y ciudad de Lérida (Lleida, Archivo Capitular, Ms. sin catalogar), fol. 46. Este último párrafo es el que ya era conocido por haberlo transcrito J. Lladonosa (La Suda, parroquia de la, pp. 41-42). He podido comprobar lo exacto de esta transcripción, gracias a la cópia del original custodiado en Lleida que me proporcionó Carmen Berlabé. 


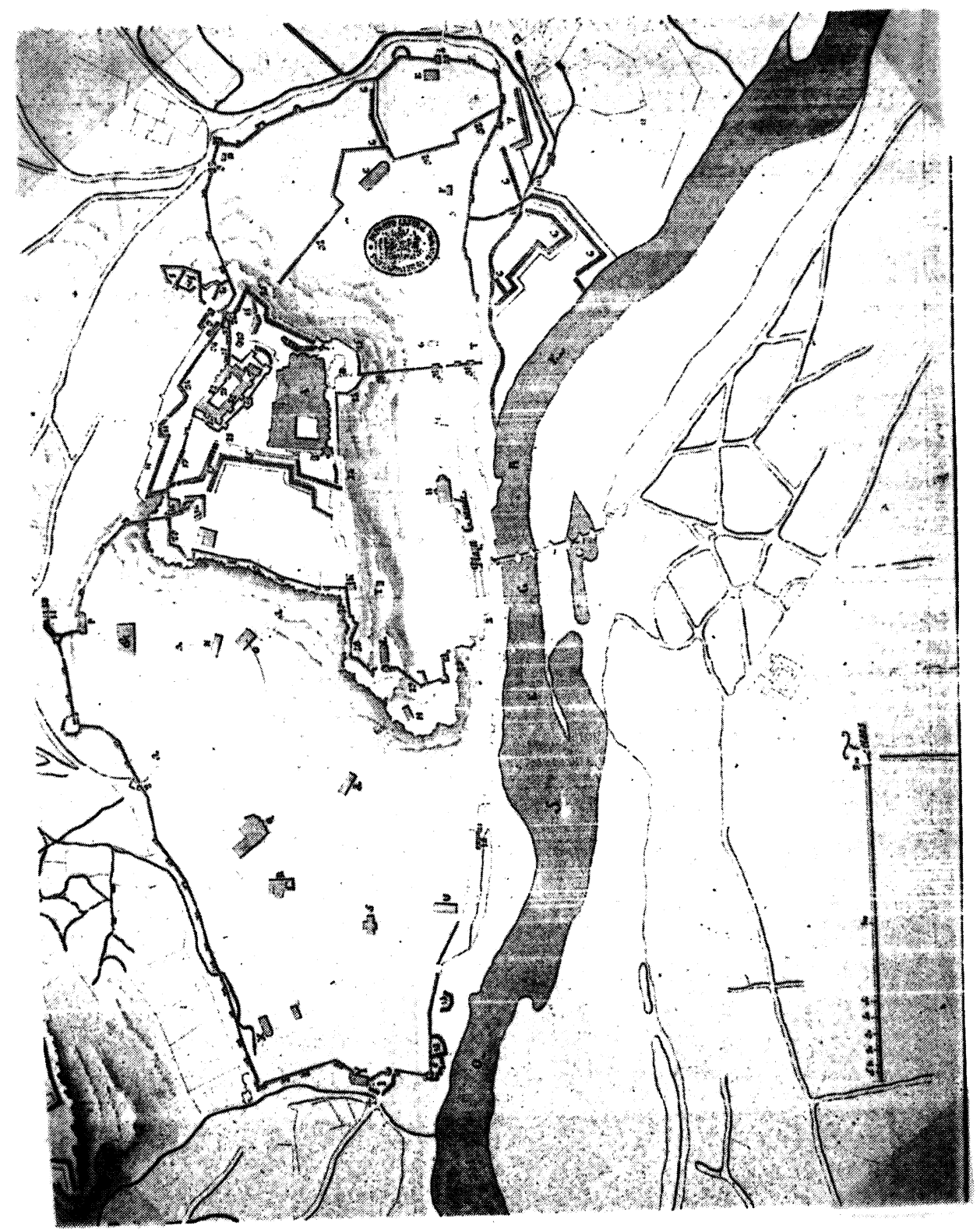

Fig. 1. Plano del castillo de Lleida (antes de 1737). Según el Atlas de Lleida. 


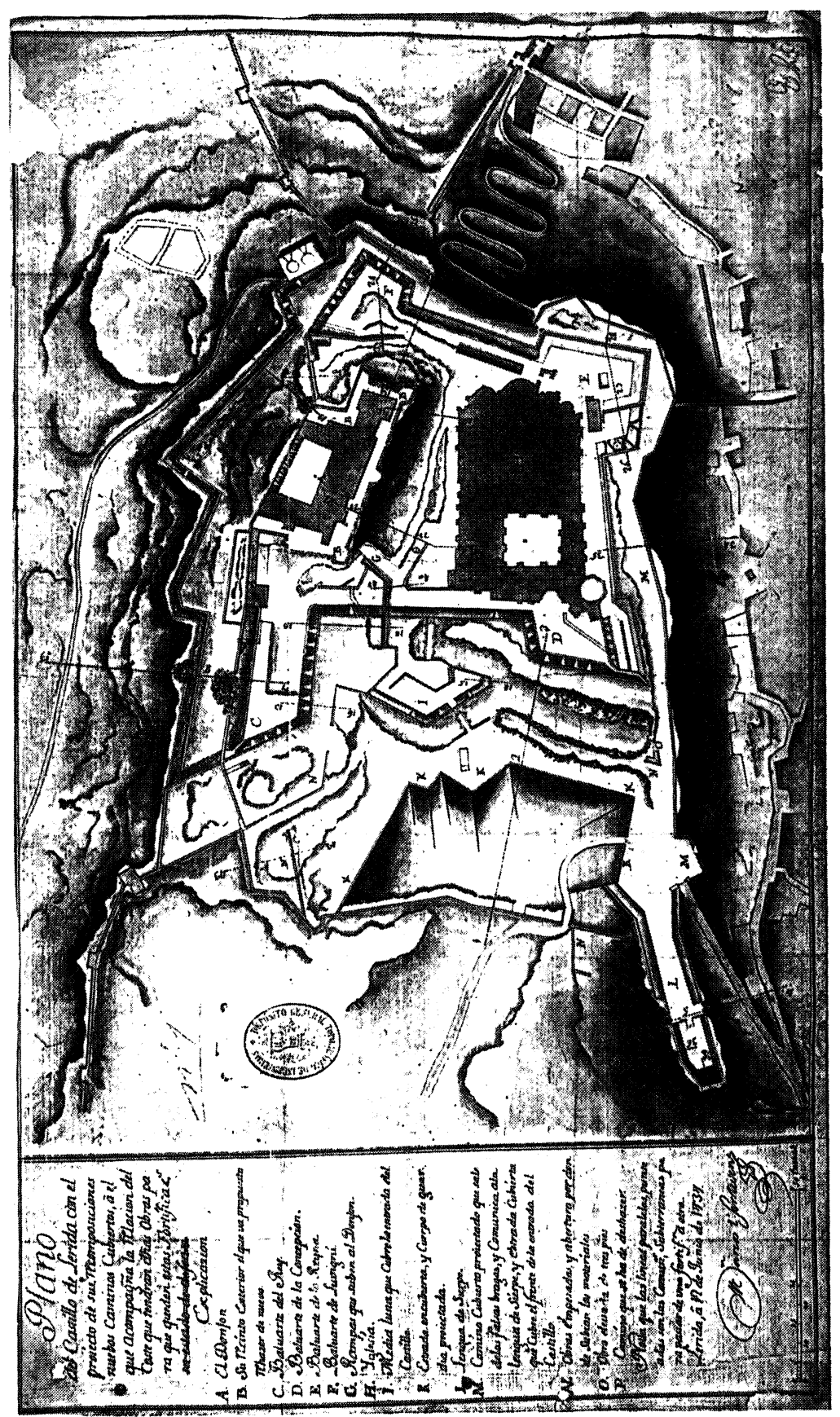

Fig. 2. Plano del castillo de Lleida (año 1737). Según el Atlas de Lleida. 
del que se conocen dos versiones que oportunamente transcribiremos, y deldiario de Francisco de Zamora radactado entre 1785 y $1790^{6}$.

Como que el acercamiento al castillo real que emprendemos, pasa necesariamente por la restitución de aquellas partes perdidas del mismo, ha resultado providencial para nuestros propósitos el hallazgo de una serie de planos militares que por su precisión tienen el valor de transportarnos efimeramente a la Zuda medieval ${ }^{7}$. Realizados en 1796, incluyen un plano general del recinto $\langle$ Fig. 8$\rangle$ y diversas secciones longitudinales y transversales de los sectores sur, oriental y occidental $<$ Figs. 9 a $13>$. Esta completa planimetría revela que las distintas alas del conjunto castral se asentaban sobre una base trapezoidal alargada en cuyo centro se hallaba el patio y que presentaban adosadas al muro exterior de los sectores occidental y sur un total de cinco torres de planta rectangular que parecen haber sobresalido por encima del nivel superior de la muralla. Entonces, la zona norte abierta a los campos a través de un mirador, según la descripción de Finestres, ya había perdido la galería abierta que existió desde época medieval y se hallaban en su lugar las troneras cuyos cimientos son aún hoy bien evidentes.

Es indiscutible que el año 1796 el castillo medieval aún se conservaba casi en su totalidad si se exceptua su sector norte. Por otro lado, también es notorio que a pesar de la pervivencia del apelativo Zuda aplicado a la construcción y de ciertos elementos que descubren un ascendente musulmán en la propia estructura, el castillo de Lleida era esencialmente un edificio gótico. Lo pone de manifiesto desde el análisis de los propios restos arquitectónicos, al material planimétrico del siglo XVIII mencionado, al igual que los datos documentales conocidos hasta ahora sobre el proceso constructivo de la fortaleza, a los que pueden añadirse otros nuevos que oportunamente daremos a conocer. Hasta ahora, sobre la base de la existencia de unos restos sin determinar de la fábrica musulmana primitiva,

${ }^{6} \mathrm{~F}$. de ZAMORA, Diario de los viajes hechos en Cataluña, Ed. de R. Boixareu, Barcelona, 1973, p. 233.

${ }^{7}$ Los planos referidos se custodian en el Servicio Historico del Ejercito de Madrid (número de inventario general 9355) Los reproducimos todos en nuestro artículo, salvo el firmado por Arajol, porque la información que proporciona es equivalente a la que dan otros ya incluidos en el Atlas de Lleida. (CATllar i Gosa, A. ARmengol i Menen, Atlas de Lleida, segles XVII-XX, Lleida 1987). Dió tambien notícia de ellos [J. FUGUET, L'arquitectura dels Templers catalans, "L'Avenç", 161 (1992), p. 66 nota 1]. Estos planos han venido a complementar la información que ya había proporcionado sobre la Roca Sobirana la recopilación de planimetrías y dibujos que se presenta bajo el título Atlas de Lleida. 
el impulso de la remodelación bajomedieval se había asignado tradicionalmente a Pedro el Ceremonioso; sin embargo, todo apunta a que este protagonismo corresponde a Jaime el Justo.

\section{El CASTILlo REAL DURANTE LOS SIGLOS XII, XIII, XIV Y XV. DATOS DOCUMENTALES}

En octubre de 1149, Lleida, capital del distrito musulman de la Marca Superior, capituló frente al ejercito de Ramon Berenguer IV y Ermengol VI de Urgell. Solo tres meses despues (enero de 1150) los dos artífices de la reconquista, coseñores de la ciudad, otorgaban la carta de población futuro marco jurídico de la nueva comunidad cristiana que iba a repoblarla ${ }^{8}$. Como de costumbre, los antiguos habitantes, pudieron optar entre trasladarse a las tierras bajo dominio musulmán o quedarse. Considerando la importancia demográfica que la población árabe tuvo en la Lleida bajomedieval, la segunda opción es la que parece haber primado.

El reparto de la ciudad y el desarrollo de ciertas áreas de la misma en los años inmediatos a la conquista, nos es conocido a partir de abundante documentación. A través de ella descubrimos la configuración de la antigua urbe musulmana y su progresiva adaptación a las necesidades de los nuevos habitantes. Asistimos a la transformación de las antiguas mezquitas en iglesias; a la remodelación de ciertos barrios y a la adaptación del antiguo alcazar a los gustos de sus nuevos señores. Esto es precisamente lo que parece haber sucedido en la Roca Sobirana. La mezquita mayor erigida en lo alto fue consagrada al culto cristiano, la Zuda pasó a depender del conde de Barcelona y del de Urgell y el barrio situado a su alrededor se fue urbanizando poco a poco a lo largo de la segunda mitad del siglo XII ${ }^{9}$.

En Lleida, además del castillo de la Roca Sobirana, se menciona la

${ }^{8}$ Sobre este punto: J.M. FONT RIUS, Cartas de Población y Franquicia de Cataluña, Madrid-Barcelona, 1969, vol. I, pp. 129-132, doc. 79; vol. II, pp. 807-810.

${ }^{9}$ Publican documentación relativa a ello o estudian el reparto de esa zona de la ciudad despues de la capitulación: J. Lladonosa, Santa Maria l'Antiga i la primitiva Canonja de Lleida (1149-1278), "Miscel.lània Historica Catalana (Homenatge al P. Jaume Finestres historiador de Poblet +1769), Abadia de Poblet, 1970, pp. 85-136 ; J. LladonOSA, Història de Lleida, I, Tarrega, 1972, pp. 248-253; J. LladonOSA, La Suda, parroquia, p. 23 i ss.; F. Castillón Cortada, El maestro de coro de la Seu Vella, de Lleida, "I", XLVII (1986), pp. 293-373. 
existencia de un palacio real junto a unos antiguos baños árabes contiguos al río Segre. Los instrumentos son inequívocos en este sentido y suficientemente precisos para haber permitido a J. Lladonosa aventurar para él una ubicación del todo convincente ${ }^{10}$ : se hallaba situado donde hoy se cruzan las calles Major y Cavallers. Designado como Palacium regis el año 1169, el rey Alfonso el Casto en un privilegio de 1172 se refiere a él como meum palacium Ilerde. Naturalmente, como en el caso de la Zuda, ignoramos cual era la situación exacta de esta residencia a propósito del coseñorio del lugar en la etapa anterior al reinado de Jaime el Conquistador (recordemos que la condesa Aurembiaix de Urgell traspasó al soberano la parte de Lleida que le pertenecía y desde entonces hubo en ella un único señor ${ }^{11}$. Este es el motivo que hace dificil asignar con absoluta fiabilidad la información contenida en ciertos documentos a uno u otro edificio.

Es el caso en concreto de una referencia fechada el año 1209 (reinado de Pedro el Católico) que todo hace pensar tiene que ver con la Zuda, aunque tal hecho no quede explícito. El soberano en un documento relativo a los Templarios señala: "et mille solidos iaccensium quos frater $\mathrm{P}$. de Monteacuto magister miliitie prestiterat nobis aput Barbastrum quos recepit P. de Sancta Cruce ad opus operis castri nostri de Ylerda"12. Indudablemente nos hallamos ante una información capital puesto que sitúa el, por ahora, primer momento de obra conocido de época cristiana en la Zuda y en unas fechas muy tempranas. Hay que advertir que entonces a los pies de este castillo se estaba edificando la nueva catedral románica (desde 1203, segun la conocida lauda fundacional conmemorativa) y que una correlación temporal en lo que respecta a las intervenciones en una u otra fábrica pudo haber implicado compartir arquitectos y artífices. Aunque no contamos con datos directos e ignoramos, por tanto, cual pudo haber sido el carácter de estas obras emprendidas, no debemos olvidar que en 1212, poco antes de su muerte, Pedro el Católico dispuso una donación a la capilla

${ }^{10} \mathrm{~J}$. LladonOSA Pujol, Las calles y plazas de Lérida a través de la historia, II, Lerida, 1979, 2da. ed. pp. 64-65. 1968.

"En lo que respecta a este tema: F. SOLDEVILA, Els primers temps de Jaume I, Barcelona,

${ }^{12}$ T. N. Bisson, Fiscal Accounts of Catalonia under the early count-kings (1151-1213), II, Berkeley-Los Angeles-London, 1984, pp. 225-226, apéndice núm. 122. 
de su castillo de Lleida ${ }^{13}$. Estaba consagrada a San Pedro y la advocación hace verosimil sospechar que el soberano pudo ser su directo promotor. Además, la cesión real invita a suponer que se trataba de un edificio recien concluído. En consecuencia, la alusión a obras de 1209 y la realidad de una capilla de San Pedro existente en 1212, no parecen hechos inconexos. Segun veremos al análizar los restos arquitectónicos que han llegado hasta nosotros y determinar las fases constructivas que descubren, este período de actividad a comienzos del siglo XIII resulta muy significativo.

Durante el reinado de Jaime el Conquistador también se llevaron a cabo reformas. Un célebre párrafo de la propia Crónica del soberano informa de estas modificaciones, aunque quizá la noticia no se ha analizado en profundidad. En el Llibre dels Feyts, leemos: "E en lloc on nos estavem lladoncs era alli on nos tenia al braç l'arquebisbe N'Asparrec, que era del llinatge de la Barca e era nostre parent, sus el palau de volta qui ara es e llaores era de fust, a la finestra on ara és la cuina, per on dóna hom a menjar a aquells que mengen en lo palau"14. Indudablemente la indicación es muy precisa. Durante el reinado de Jaime, se construyó una nueva cocina en la Zuda y fue sustituida la cubierta de madera del palacio por una bóveda. Esta noticia documenta la existencia de un salón que podría haberse construido ex-novo despues de la conquista, o tratarse de un ambito preexistente que se habría reformado en época cristiana, pero en todo caso el énfasis está puesto claramente en el cambio de su cubierta. Es importante esta transformación de la que se habla puesto que ha dado pie a especulaciones sobre su exacta localización. Volveremos más adelante sobre este punto. Lo que ahora nos interesa es situar el momento aproximado de esta remodelación.

Los hechos a los que alude el monarca en su crónica sucedieron en 1214, con motivo de la asamblea celebrada en Lleida poco después del fallecimiento de su padre, siendo Jaime todavía un niño (sólo contaba seis

\footnotetext{
${ }^{13}$ En mayo de 1212 está documentada una donación de Pedro el Católico a la capilla de su castillo leridano, prueba inequívoca de su existencia. Barcelona, ACA, Pergamino 425 de Pedro el Católico. Da notícia de él: J. MIRET Y SANS, Itinerario del rey Pedro I de Cataluña II de Aragón, "Boletín de la Real Academia de Buenas Letras de Barcelona", IV (1907), pp. 32-33. Se refiere también a ella: J. LladonOSA I PUJOL, Història de Lleida, I, p. 297. En lo concerniente al patronazgo ejercido por los monarcas sobre las capillas de sus residencias, véase tambien la nota 37.

${ }^{14} \mathrm{Se}$ trata del capítulo 11 .
} 
años) ${ }^{15}$. Recordemos que en el Llibre dels Feyts se han delimitado cuatr partes y que este episodio se incluye en la primera de todas ellas que comprende el período 1208-1228. Los términos en los que se detalla lo sucedido son claros: la asamblea tuvo lugar en el palacio que entonces (es decir en 1214) tenía cubierta de madera y "ahora" (el momento de la redacción de este capítulo de la crónica) ostenta bóveda. Los historiadores han situado en las proximidades de 1244 la conclusión de las dos primeras partes del $\operatorname{libro}^{16}$. Aunque las interpolaciones son un hecho muy habitual en esta época y una observación del tipo el palau de volta qui ara es puede serlo, los especialistas no se han pronunciado respecto al texto que tratamos en este sentido $\mathrm{y}$, en consecuencia, parece lógico considerar que estamos ante una precisión del monarca contemporánea a la redacción original.

Por lo tanto, de todo ello se deduce que entre 1214 y 1244 se llevaron a cabo intervenciones en la fábrica del castillo real de Lleida, continuación seguramente de las que ya se habían emprendido durante el reinado de Pedro el Católico. Aunque en esta etapa temprana pudiera haberse tratado primordialmente de adaptaciones necesarias a los habitos de los nuevos señores (y la capilla podria ser paradigmática de lo que apuntamos), no creemos que deba dejarse de considerar otra alternativa: que por entonces se estuviera reconstruyendo integramente el castillo segun la denominada tipología Felipe Augusto que circuló extensamente por el occidente europeo, y que en Lleida se mantuvo, a pesar de que las habitaciones dispuestas alrededor del patio central acusaron transformaciones posteriores.

Volviendo de nuevo al palau aludido por Jaime I, recordemos que en época medieval recibía este nombre el ámbito más solemne de las residencias señoriales, aquel donde el soberano o el noble se mostraban como tales ${ }^{17}$. En consecuencia, no se trataba de un edificio sino de una parte del mismo. Por el papel que a causa de su situación geográfica asumió la Lleida cristiana en el contexto de la Corona de Aragón, la celebración de las cortes generales recayó muchas veces en la ciudad. Se hacía necesario, por tanto, un espacio idóneo, y alguna de las amplias salas con que contó el

\footnotetext{
${ }^{15}$ Véase: F. SOLDEVILA, Els primers temps.

${ }^{16}$ M. DE RiQuer, A. Comas, Història de la Literatura Catalana, I, Barcelona, 1980, 2 da. ed. p. 407.

${ }^{17}$ Sobre la significación del término palacio véase: J. RUBIÓ BALAGUER, Vida española en la época gótica, Barcelona, 1943, p. 71 y ss.
} 
castillo real tuvo que destinarse esporádicamente a ese fin. Pero la asamblea general de 1214 fue la primera de todas. Yo creo que el palau donde se celebró, y cuya cubierta se remodeló más tarde, no tenía porque ser una sala de amplias dimensiones. Debió tratarse de un espacio con cierre de madera que, dependiendo de sus dimensiones, incluiría o no arcos diafragma, una solución de gran funcionalidad y perfectamente afín al período ${ }^{18}$. Aunque ciertos historiadores han sido proclives a identificar este ámbito, con el ala sur del castillo que se ha conservado parcialmente y que acusa una modificación de este tipo en su cubierta ${ }^{19}$, aceptar tal posibilidad, como veremos, se hace difícil.

El reinado de Jaime I coincide con el establecimiento en la ciudad de Lleida y en parte por su directa intervención, de una dinastía de maestros de obra que tendrá una vinculación muy estrecha no sólo con la catedral sino con el propio castillo, siendo cuatro de sus miembros custodios del mismo. Nos referimos a la familia Prenafeta ${ }^{20}$. Pere de Prenafeta, el primero documentado (si se excluye la pertenencia al clan de un Ramon de Prenafeta registrado en ámbito leridano con anterioridad), fue maestro mayor de la catedral y probablemente custodio de la fortaleza hasta su muerte acaecida en 1286. La primera notícia conocida sobre el artífice data de 1259. Entonces el soberano le concedió en franco alodio la torre de Besora localizada al este de la Roca Sobirana. El mismo personaje fue objeto nuevamente de la magnanimidad del rey Jaime en 1273. En esta ocasión le fue otorgada una cantera situada en el patio de la referida torre. Falleció en 1286 segun informaba una lápida conmemorativa existente en el claustro de la catedral.

Un hijo de Pere de Prenafeta llamado Ramon y lapicida como su padre, era custodio del castillo en 1297. Por entonces ya debían de haber nacido todos sus hijos habida cuenta que alguno consta incluso como mayor de edad. Tuvo seis. Dos de los varones siguieron la tradición familiar y fueron lapicidas y, sucesivamente, custodios de la residencia del monarca en Lleida. El primero, Pere, fue nombrado maestro de obras del rey el año

\footnotetext{
${ }^{18}$ L. TORRES BALBÁs, Naves cubiertas con armaduras de madera sobre arcos perpiaños a partir del siglo XIII, "Archivo Español de Arte", XXXIII (1960), pp. 19-43

${ }^{19}$ J. Lladonosa, La Suda, parroquia, p. 36.

${ }^{20}$ Para todas las noticias referentes a la familia Prenafeta que siguen: F. ESPAÑOL BERTRAN, La catedral de Lleida: arquitectura y escultura trescentistas, "Congrés de la Seu Vella", pp.184186 y los apéndices 1 al 17, así como la figura 20.
} 
1297 y a la par se le designó para que a la muerte del padre le sucediera en la salvaguarda de la fortaleza. Lo documentamos entre 1297 (ya entonces mayor de edad) y 1312, momento probable de su muerte. El segundo se llamaba Domènec y vivía aún en 1328. A pesar de que ignoramos el momento, ni siquiera aproximado de su óbito, como que hacia 1336 la Zuda ya tenía un nuevo obrero, debemos sospechar forzosamente su desaparición entre ambas fechas.

El margen cronológico delimitado por la vinculación de los Prenafeta a la Zuda es aproximadamente de unos sesenta y nueve años: del 1259 al 1328. Un periodo dilatado que abarca los reinados de Jaime el Conquistador, Pedro el Grande, Alfonso el Liberal y Jaime el Justo y que coincide con la obra de buena parte de la catedral. Es incontestable la dedicación del primer Prenafeta a los dos edificios, pero seguramente otros integrantes de la dinastía compartieron también ambas responsabilidades. En todo caso, la adopción de determinadas soluciones formales en una y otra fábrica es un argumento a favor de esta hipótesis, ya que tal hecho sólo puede responder a una razón: maestros comunes durante períodos afines.

Estas constataciones formales las desarrollaremos en capítulo aparte, pero ahora interesa recoger las notícias documentales que avalan directamente las intervenciones en nuestro edificio. Durante el gobierno de Jaime el Justo se registran importantes reformas. Por un lado, en 1299 el rey se pronunció a favor de construir una carcel en el interior del castillo con dos estancias destinadas respectivamente a hombres y mujeres ${ }^{21}$. Unos años después (1316) dio orden a Berenguer de Palau ${ }^{22}$ de incorporar vidrieras a las ventanas de la capilla (el mismo artífice haría lo propio al año siguiente en la capilla del Reial de Valencia ${ }^{23}$ ). Quizá no debamos dejar de relacionar estas modificaciones con la concesión en 1313 de la capellanía del castillo

\footnotetext{
${ }^{21}$ Lleida, Archivo Municipal, privilegio 63. Da a conocer este dato: E. MUT REMOLÀ, La vida económica en Lerida de 1150 a 1500, Lérida 1953, p. 150. Aunque por los términos del documento hemos creído que podría tratarse de una cárcel localizada en el castillo, debemos reconocer que también es viable entender que se refiera de forma genérica al barrio de la Zuda.

${ }^{22}$ Barcelona, ACA, Cancillería, Jaime II, registro 277, fol., 292 v.

${ }^{23} \mathrm{M}$. DE BARCELONA, La cultura catalana durant el regnat de Jaume II, "Estudis Franciscans" (en lo sucesivo E.F.), 92 (1991), p. 394, doc. 319. El documento está fechado el 30 de abril de 1317.
} 
real a Ramon Guasch ${ }^{24}$.

Contemporáneamente, aunque por ahora no entramos a valorar la importancia de esta intervención, debió reformarse el salón principal de la fortaleza ya que constan haberse fabricado nuevas puertas para el palacio ${ }^{25}$. En el transcurso de 1315 y 1316, el soberano buscó los medios para financiar este conjunto de obras y diversas órdenes localizadas entre la documentación de Cancillería lo avalan ${ }^{26}$. También es el momento en el que el imaginero Francesc de Montflorit informó al monarca desde Lleida que había concluído dos figuras: una a su imagen y otra a la de Blanca de Anjou. Sucedía el 3 de marzo de $1313^{27}$. El estado del documento no permite una lectura continuada, pero de sus términos parece desprenderse que estaban destinadas a una capilla (¿la del castillo?). Yo en otra ocasión y con motivo de estas imágenes ya he especulado con la posibilidad de que se tratara de piezas destinadas a embellecer la residencia real de la ciudad ${ }^{28}$.

Durante este período fueron maestros de obras reales Pere de Prenafeta y su hermano Domènec. De sus respectivas posiciones es forzoso conjeturar su intervención en las reformas referidas, y su responsabilidad como custodios. Como tal hubo de actuar el primero, por ejemplo, al recibir una orden del monarca (26 de junio de 1312), indicándole que permitiese coger del castillo al arcediano de Tarantona de la catedral de Lleida (entonces Ramon de Muntanyana), toda el agua que necesitase y también usar las cámaras del mismo que le fueran necesarias ${ }^{29}$. La custodia de los castillos reales recayó también en otras ocasiones en manos de profesionales de la construcción, preparados, por tanto, para salvaguardar mucho mejor las fábricas que se les encomendaban. Puede que los Prenafeta sean un caso singular por su larga vinculación al cargo, pero el nombramiento del maestro de obras Guillem Carbonell como custodio del palacio de la reina en

\footnotetext{
${ }^{24}$ Barcelona, ACA, Cancillería, Jaime II, reg. 210, fols. 35-35 v. Se trata de dos registros, El primero trata de la concesión a Pere Guasch de la capellanía del castillo real de Lleida, en el que sigue se informa al baile de la ciudad del mismo asunto.

${ }^{25}$ Barcelona, ACA, Cancillería, Jaime II, reg. 277, fol., 283. El documento está fechado a 9 de octubre de 1316 .

${ }^{26}$ Barcelona, ACA, Cancillería, Jaime II, reg. 277, fols. 86 v. (21 febrero 1315), y 192 v. (3 junio 1316).

${ }^{27}$ M. DE BARCELONA, La cultura catalana, "E.F.", 92 (1991), pp. 474-475, doc. 465. 220 .

${ }^{28} \mathrm{~F}$. EsPañol BerTRAN, Clients i promotors en el gòtic català, en: Catalunya Medieval, p.

${ }^{29}$ F. ESPAÑol BerTRAN, La catedral de Lleida, p. 206, apéndice núm. 9.
} 
Barcelona en1368, o el de Bernat Boix para el de Valencia en $1376^{30}$, confirman lo que apuntamos.

En el transcurso del gobierno de Alfonso el Benigno las reformas continuaron. Por un lado, contamos con una noticia que registra la incorporación de unos pannos depictos a las ventanas de la capelle nostri castri civitatis Ilerde... ${ }^{31}$, por otro, sabemos que el infante Pedro dio diversas ordenes de pago en 1334 por este concepto. A lo largo de los meses de marzo, abril y mayo consta que se entregaron a Çalema Moreno, un musulman de la ciudad, diversas cantidades con el fin de abonarle el total que había adelantado para hacer frente a diversos gastos: la reparación de unas vidrieras y de las ventanas correspondientes, así como la adquisición de una campana que se hacía sonar durante la celebración de la misa ${ }^{32}$. Ignoramos si ya por entonces Samsó de Navers era operario del castillo. Quizá aún no. El primer documento que lo menciona (29 de agosto de 1336) data de los primeros meses del reinado de Pedro el Ceremonioso. Por él nos informamos nuevamente de la existencia de trabajos en la Zuda: "illius operis quod de novo operatur in dicto castro" ${ }^{33}$, se dice. Precisamente la orden del monarca pretende conseguir una casa para guardar las herramientas: "in qua possit ponere seu poni facere ferramenta vel alia aparamenta circa dictum opus necessaria". Aunque puede haberse interpretado en algún caso como indicación de obras importantes en el castillo, la carta que el rey escribió al baile de Lleida el 16 de marzo de 1341 ordenándole librar

\footnotetext{
${ }^{30} \mathrm{P}$. DE BOFARUll y MASCARÓ, Procesos de las antiguas cortes y parlamentos de Cataluña, Aragón y Valencia ("Colección de documentos inéditos del Archivo de la Corona de Aragón", VI), Barcelona, 1850, pp. 343-347, doc 102. A. RUBIÓ I LLUCH, Documents per a la història de la cultura catalana migeval, II, Barcelona, 1921, p. 180, doc. CXCIII.

${ }^{31}$ J. TREnChs Odena, De l'Estudi General a la Seu: la confecció de llibres a Lleida durant el segle XIV, "Congrés de la Seu Vella", p. 140, doc. 1

${ }^{32} \mathrm{~J}$. MUTGÉ I VIVES, L'aljama sarraïna de Lleida a l'Edat Mitjana. Aproximació a la seva història, Barcelona, 1992, pp. 51-53 y apéndices núms. 115, 116, 117. En el primero leemos: "...expenderit, de suo proprio, in opere seu aptacione quarundam fenestrarum seu speculariorum capelle castri civitatis predicte..." (1334); "... in empcione cuiusdam tintinabuli quod pulsatur ad sacrifficium in capella castri dicte civitatis ac, etiam, in quibusdam operibus et aptacionibus portarum et tabularum ac aliarum rerum..." (1334).

${ }^{33}$ J. RiUS SERRA, Més documents de cultura catalana medieval, "Estudis Universitaris Catalans", XIII (1928), p. 143, apéndice XVI. Publica otra noticia relativa al mismo personaje: M.D. MATEU IBARS, Documentos de 1306, 1310, 1336, y 1339 referentes a obras en el "castrum Ilerdae", "I", XL (1979), p. 233, doc. III. En este caso se trata del permiso real al hijo de Samsó (Bernat de Navers) para extraer mil piedras de la cantera del castillo, destinadas a la reparación de las paredes de cierta casa.
} 
anualmente los 1000 sueldos al mencionado Samsó ${ }^{34}$ ("operario castri nostri civitatis eiusdem"), debe entenderse desde otra perspectiva. Ciertamente, según indica el documento ("convertendos et exponendos per eum in opere dicti castri") los trabajos continuaban, pero era así desde el siglo XIII porque esta orden no alude a otra cosa que al montante destinado anualmente, desde el siglo anterior, a sufragar los gastos de mantenimiento del castillo ${ }^{35}$.

La capilla, que existía a mediados del siglo XIV (por fuerza distinta de la documentada a principios del XIII), fue uno de los ámbitos más espectaculares de la Zuda. Como revela el análisis detallado de su fábrica (en este punto anticipamos resultados) hay que atribuirla a Jaime el $\mathrm{Justo}^{36}$, pero, siendo así, también es obligado reconocer a la iniciativa de Pedro el Ceremonioso su definitiva configuración interior. A partir de 1346, hay abundantes indicios que conducen a esta interpretación y uno de los más decisivos es la institución por parte del rey de cuatro beneficios en ella precisamente ese $a \tilde{n} \mathrm{o}^{37}$. Por otro lado, data de entonces el encargo al pintor Ferrer Bassa de los retablos que debían presidirla. El proyecto puede seguirse desde el mes de enero de 1345 , momento en el que el tesorero real hizo efectiva una cantidad al artífice por ese concepto ${ }^{38}$. Contamos también con una alusión del monarca que puede ser interpretada en esta misma línea. En un documento de 1356 leemos: "la capella de nostre castell de Leyda que

\footnotetext{
${ }^{34}$ J. RiUS SERRA, Més documents de cultura, p. 159, apéndice LII.

${ }^{35}$ Se hallan referencias al destino regular de una cantidad para obras en el castillo desde el siglo XIII. Notícias sobre ello en P. BERTRAN, Notes sobre la fiscalitat reial a la ciutat de Lleida (1341-1351), "Miscel-lània Homenatge a Josep Lladonosa", Lleida, 1992, p. 262: "Item és acostumat que se'n leva per obra del castell $M$ sous, los quals romanen a la part del senyor Rey".

${ }^{36}$ Véase más adelante el apartado $\mathrm{V}$ del trabajo.

${ }^{37}$ Pedro el Ceremonioso fundó un total de cuatro beneficios el 23 de enero de 1346. Recordemos que el caracter del patronazgo real sobre las capillas localizadas en los palacios fue definiéndose sobre todo en la época de Jaime II y Pedro el Ceremonioso, aunque alcanzó su desarrollo mayor a finales del siglo XIV. Sobre este tema: J. VINCKE Das Patronatsrecht der aragonischen Krone, "Spanische Forschungen der Görresgesellschaft", I Reine, 10 Bd.(1955), pp. 55-95; también: G. RoHFLEISCH, Der Ausbau der Pfalzkapelle zu Valencia druch Peter IV von Aragon, "Homenaje a Johannes Vincke", I, Madrid, 1962, pp. 183-192. J. VINCKE, El derecho de patronato de la Corona de Aragón en el reino de Valencia, "Primer Congreso de Historia del Pais Valenciano", II, Valencia, pp. 837-849.

${ }^{38}$ F.P. VERRIÉ, Una obra documentada de Ramon Destorrents, "Anales y Boletín de los Museos de Arte de Barcelona", VI (1948), p. 339, doc. I; J.M. Madurell Y MARIMON, El pintor Lluís Borrassà: su vida, su tiempo, sus seguidores y sus obras, "Anales y Boletín de los Museos de Arte de Barcelona", VIII (1950), p. 11, apéndice 3.
} 
novellament havem feta fer" ${ }^{13}$. Aunque en principio estos términos parecen aludir a una nueva construcción, en el periodo que tratamos podían aplicarse igualmente a la institución de una capilla, es decir de un nuevo culto en el seno de un edificio preexistente. Considerando las características morfologicas de la construcción leridana (de las que nos informan los planos de finales del siglo XVIII y también antiguas fotografías de este sector, realizadas cuado ya estaba en estado ruinoso, pero aún no había desaparecido) se hace dificil conciliar la fabrica con un periodo avanzado dentro del siglo XIV como lo es el del rey Pedro.

Volviendo nuevamente al retablo que realizaba Ferrer Bassa, ignoramos cual fue su dedicación precisa. Si se trató de uno sólo, obviamente, el titular debió ser San Pedro, pero no podemos hacer otra cosa que constatar la omisión de este extremo en los documentos que se refieren a él, incluso poco explicitos en lo que respecta a su número exacto. Conocemos, eso sí, ciertas circunstancias que rodearon la consecución de la obra. Sabemos, por ejemplo, que el pintor se retrasó en el cumplimiento de los plazos pactados. Ha sido localizada una carta del rey en la que se hace eco de una enfermedad del pintor. Está fechada en Lleida el 7 de septiembre de $1346^{40}$. Poco despues el día 17 del mismo mes el soberano escribe de nuevo a Bassa reclamándole "illas rectabulas quas ad opus capelle castri nostri Ilerde fecistis de mandato nostro..."41. Suponemos que el pintor concluyó finalmente la obra ya que en años posteriores se documenta la incorporación de una cortina para protegerla (Lleida 15 de marzo de $1356)^{42}$ y de un guardapolvo que fue realizado por el pintor de Barcelona Ramon Destorrents con el mismo objeto ${ }^{43}$.

Si bien el interior de la capilla real hubo de quedar totalmente terminado en este período, el rey continuó preocupándose por su decoro en los años inmediatos. Existe un documento datado en Zaragoza el 12 de

\footnotetext{
${ }^{39}$ J. TREnChS I OdEnA, De l'Estudi General, p. 140, doc. 7.

${ }^{40}$ Ibidem, p. 140 , doc. 4

${ }^{41}$ A. RUBió I LluCh, Documents per l'historia, I, Barcelona, 1908, p. 139, doc CXXXII; S. SANPere y MiQuel, Els Trescentistes. Primera Part, Barcelona, s.a. (1920), p. 232; M. TRENS, Ferrer Bassa $i$ les pintures de Pedralbes, Barcelona, 1936, p. 173, ap. XXXI; J. TRENChS I Odena, De l'Estudi General, p. 140, doc. 5.

${ }^{42}$ Ibidem, p. 140 , doc. 7.

${ }^{43}$ Ibidem, p. 140 , docs. 8 y 9 . El segundo ya había sido publicado por: A. RUBIÓ I LLUCH, Documents per l'història, I, p. 178, doc CLXXIV.
} 
octubre de 1381, que nos informa de un nuevo proyecto en relación a ella. En este caso se trata de la incorporación de una tribuna de madera ${ }^{44}$. La misma que descubren los planos levantados a finales del siglo XVIII, antes de la destrucción definitiva de este espacio y prueba inequívoca de que los deseos del monarca se cumplieron.

Contemporáneamente a este interés del rey por la capilla real, otras áreas del castillo eran también remodeladas. Es el caso de la estáncia se cita en un documento del 1339 como camera...Blanca, y que se hallaba situada precisamente detrás del ámbito cultual. Este mismo apelativo también daba nombre a otras estancias existentes en los palacios reales de Perpiñan, Barcelona y Valencia, sin que sepamos por ahora el motivo exacto, aunque todo lleva a deducir que derivaría del color de sus muros ${ }^{45}$. Segun se indica en la orden real se hacía necesario repararla ${ }^{46}$. En otra ocasión la que se menciona es la cambra nostra e de la regina, cuyo techo debía embellecerse con hoja de oro y plata, segun noticia del año $1346^{47}$. Tenía que tratarse por fuerza de una cubierta de madera del mismo tipo que las existentes en otros castillos reales como los de Tortosa, Tarragona, Barcelona etc. ${ }^{48}$

Los documentos medievales muchas veces aluden a habitaciones del castillo difíciles de ubicar. Es el caso de la cámara que acabamos de citar, quizá la misma para la qua se adquirió una tina el año 1367 por orden de la reina Leonor $a$ obs de fer bany..., ${ }^{49}$ pero también del estudio mencionado el año 1375 en el que se guardaban ropas y libros ${ }^{50}$.

\footnotetext{
${ }^{44}$ Aunque no se trata del mismo género de obra, a propósito de esta tribuna de madera que se coloca en la capilla leridana, puede tomarse en consideración el aprecio que parece haber tenido el Ceremonioso por las cubiertas de tradición mudejar. Las hubo en el castillo de Tortosa y en el de Tarragona. Para las del primero véase la documentación publicada por: J.M. MADURELl MARIMON, El pintor Lluís Borrassà, VII, 1949, pp. 201-202, reg. 590; VIII, 1950, p. 41, ap. 33; IX, 1952, p. 85, ap. 482-483.

${ }^{45}$ Recoge todas estas referencias: M. DuRLiAT, L'Art en el Regne de Mallorca, Mallorca, 1964 p. 175.

${ }^{46}$ M.D. MATEu IBARS, Documentos de 1306,1310 , p. 234 , doc. IV

${ }^{47} \mathrm{~J}$. TRENCHS I ODENA, De l'Estudi General, p. 140, doc. 3

${ }^{48}$ J.M. MAdurell y Marimon, Pere el Cerimoniós i les obres públiques, "Analecta Sacra Tarraconensia", XI (1935), pp.374, 383-383, docs. 4 y 5.

${ }^{49} \mathrm{La}$ noticia se refiere a la adquisión "d'una tina o banyadora que de manament de la dita senyora (Eleonor de Sicilia) ha comprada en la ciutat de Leyda a obs de fer bany en la cambra", Barcelona, ACA, Real Patrimonio, Maestro Racional, vol. 489, fol. 62. Noticia transcrita y publicada por R.CONDE, Pere el Cerimoniós (1336-1387). Exposició documental (catálogo de exposición), Barcelona 1987, doc. 1.

${ }^{50}$ J. Trenchs I Odena, De l'Estudi General, p. 144, doc. 163.
} 
Por el momento, no disponemos de tantas noticias sobre el castillo para el siglo XV o los últimos del XIV como las tenemos para el período anterior, claro indicio de una progresiva pérdida de interés por parte de los soberanos hacia la fortaleza. Ahora bien, en 1366, restaba aún por erigir uno de sus elementos más emblemáticos: la que fue conocida como Torre dels Jueus, ubicada en el sector oriental y designada con este apelativo porque fue esta minoría la encargada de financiarla. Se trataba de una magnifica torre señorial de planta rectangular y dos pisos de altura <Figs. 12 y $13>$ en cuya construcción, a pesar de su suntuosidad, no se dejó de lado la función militar que le estaba reservada, ya que fue levantada con motivo de la guerra con Castilla. Recordemos que por entonces también se fortificó la ciudad y que el encargado de conducir los trabajos fue el hospitalario Fra Guillem de Guimerà que supervisó por entonces el estado de las murallas en otros lugares de Cataluña ${ }^{51}$. Se documentan contribuciones para las obras del castillo los años 1366 y 1367, pero quizá las obras se pospusieron un tiempo puesto que en 1408 el rey Martín el Humano se refería a él en estos términos: "Scientes castrum nostrum civitatis Ilerde tanta fuisse annosa corrosione destructum quod nisi cura nostra regalis circa eius reparationen se pronam et facilem exhiberet posset faciliter exesa vetustate cosumeri soloque penitus adequarise prolongaro" 52 .

Probablemente, esta fue la última intervención de envergadura en el edificio medieval. Más tarde se rastrean puntuales noticias que aluden a trabajos de restauración como por ejemplo los registrados tras la guerra civil catalana del siglo XV en la Torre dels Jueus ${ }^{53}$, pero son hechos más o menos aislados. La historia arquitectónica de la Zuda de Lleida se desarrolla paralelamente al flujo de los siglos medievales pero no se prolonga más allá.

\footnotetext{
${ }^{51}$ Sobre Fra Guillem de Guimerá en Lleida: J. Lladonosa I Pujol, Història de Lleida, I, p. 482. Sobre la labor de este hospitalario en el campo de las fortificaciones catalanas durante la segunda mitad del siglo XIV (monasterio de Poblet y Cervera): F. CARRERAS Y CANDI, Idea de l'avenç urbà de Catalunya al segle XIV, "III Congreso de Historia de la Corona de Aragón" (Valencia 1923), I, Valencia, 1924, pp. 165-228.

${ }^{52}$ Da noticia de las contribuciones: J. LladonOSA I Pujol, Història de Lleida...I, p.481. Publica el documento de la concesión de 100 florines para las obras por parte de Martín el Humano: T. DE MONTAGUT I ESTRAGUÉs, El Mestre Racional a la Corona d'Aragó (12831419), Barcelona, 1987, II, doc. 45, pp. 79-80.

${ }^{53}$ J. Lladonosa I Pujol, Història de Lleida, I, p. 725.
} 


\section{LAS DESCRIPCIONES ANTIGUAS DEL EDIFICIO Y LA SERIE DE MAPAS MILITARES DE 1796}

Es evidente que el conocimiento del antiguo castillo real de Lleida no puede sustentarse únicamente en lo que revela la arqueología. El edificio ha llegado hasta nosotros demasiado deteriorado en determinadas zonas, para que unos resultados en este campo sean suficientemente satisfactorios. Las fuentes antiguas se convierten por este motivo en instrumentos muy valiosos para el historiador y dentro de este capítulo podemos considerar tanto los datos documentales ya analizados, como las descripciones de la fábrica previas a su destrucción, o bien el conjunto de planos de la fortaleza anteriores a las amputaciones más relevantes que esta sufrió.

Presentaré en primer lugar aquellos apartados que ciertos autores del siglo XVIII han dedicado a la antigúa Zuda de Lleida y que hoy resultan fuentes de primera mano en un acercamiento a ciertas áreas perdidas del edificio. El primer historiador al que recurrimos es el canónigo Pere Joan Finestres, autor de un malogrado Fragmento histórico de la Catedral, Yglesias y Ciudad de Lerida. La obra nunca llegó a editarse y en gran medida podemos darla hoy por perdida. En el Archivo Capitular leridano se conserva la redacción íntegra de uno de los capítulos: el que se dedica a la ciudad de Lleida bajo el epígrafe Descripción de la ciudad de Lerida, de su obispado y territorio secular y eclesiástico, sus antigüedades y cosas notables. De él hemos tomado el párrafo " $a$ ". La copia de algunos apartados de esta misma obra, que en algun caso parecen borradores de la misma, pertenecieron al erudito premostratense Jaume Pasqual y se hallan incorporados, sin orden alguno, en el segundo volumen de sus Sacrae Antiquitatis Catalonia Monumenta. Hemos sacado de ellos los dos fragmentos restantes que transcribimos de Finestres " $b$ " y " $c$ ". El tercero " $d$ " procede de los apuntes que tomó Francisco de Zamora en su Diario...

a): Al mismo tiempo pertenece la fabrica del castillo de Gardeny y aunque parece ser de la misma trasa y mano del castillo de los condes. Estas fabricas son de piedra muy bien labrada con algunos adornos en los ...miras (?) los salones muy espaziozos y toda la obra bien ünida, arcos fuertes y travados entre si con otros arcos que de las esquinas de los mayores salen a lo alto de las bovedas donde se unen en una piedra que sirve de llave. No tenian cubierta de texas sino de piedra labrada haziendo una buena galeria y mirador para lograr mas descubierta la vista de la espaciosa campaña. Las puertas eran pequeñas $y$ respecto de la gran fabrica lo eran tambien las 
principales que davan la entrada y salida al Palacio. Aun con ser tan altos los miradores que corren lo alto de la fabrica puesto en lo mas elevado del terreno del monte en que esta fundado, tenia el Palacio de los Condes algunas torres de bastante elevación y sin duda como a fabrica real serian quatro, una en cada angulo de la dilatada fabrica, de las quales ahora solo quedan dos que son la que mira a lo principal de la ciudad y al puente. A la parte de Tramontana que es la opuesta a la de las dichas torres hay un grande passillo de mas de 200 pasos de largo y poco menos de 100 passos de ancho segun se discurre por los vestigios que quedan corria una (ilegible) de columnillas para sustentar otra galeria mas baxa igual a los quartos de la habitacion que ya no parece y que se quitó para componer la defensa del castillo a lo moderno, pues en la muralla exterior se abrieron troneras para la artilleria que alcanza buena parte de la huerta que le corresponde y está baxo (ilegible). No se deve dudar que ciñese a esta fabrica mucho por todas partes assi porque era estilo de los señores cerrar con murallas sus palacios porque este terreno era a propósito para la fortaleza pues todas sus circunstancias qual fuese el muro no es fácil de distinguirle despues de tantas nuevas obras que se han hecho en aquel recinto... ${ }^{54}$

b): El castillo de Lerida puesto en lo mas alto del monte en que la ciudad esta fundada puede ser sea parte del tiempo de los moros porque se halla que en los primeros años despues de ganada la ciudad por el Conde de Barcelona se llamava la Azuda que es termino que era usado de los africanos, y con esta partida vezina se llamó del mismo nombre y quedó por muchos años el nombre a una plaza que siempre se dize de la Azuda, pero lo mas es de fabrica posterior y sin duda para Palacio y Casa Real que habitaron Reyes y Condes de Urgel, Señores de Lerida despues de la conquista. A este mismo tiempo pertenece el castillo de Gardeny distante solo un tiro de piedra del de Lerida, edificio situado en el collado immediato a la ciudad azia poniente que se crehe sea el que avanço e (ilegible) Cesar con grande trabaxo para desaloxar de el a los capitanes Pompeo y Cayo (ilegible) que por su estilo atribuyen otros al mismo Cesar y es sin duda que no avia entonses fortaleza pues nada se dize de ella que avia sido honor de casar... ${ }^{55}$.

c): La capilla del Palacio Real estava dentro de la cerca del Palacio de los Condes de Urgel que tenian en la ciudad de Lerida en feudo, y despues

${ }^{54}$ P.J. FiNESTRES, Fragmento histórico de la catedral, iglesias y ciudad de Lérida (fragmento de la obra en: J. PASQuAL, Sacrae Antiquitatis Cathaloniae Monumenta, II, fol. 140), Barcelona, Biblioteca de Catalunya, Ms. 729.

${ }^{55}$ P.J. FineSTRES, Fragmento Histórico (fragmentos de la obra en: J. PASQUAL, Sacrae Antiquitatis, II, fol. 201 v.). 
sucediendo al Condado de Urgel los Reyes de Aragon, se ennoblecio con el título de Palacio del Rey. Dos son las que puede competir esta honra porque no consta qual era la que se tenia por Capilla Real y es muy natural que ambas lo hayan sido; segun los vestigios que aun quedan del Palacio, que al presente es Almazen de Armas y aprestos militares y quartel de los soldados de su custodia, havia en la parte de tramontana un anchuroso patio, por la parte de poniente cerrado con una pieza capaz de una mediana iglesia, por la parte del Mediodia y de Levante le cerravan las paredes del Palacio y salas espaciosas de su habitacion y por septentrion una galeria muy alegre y de (extendido prospecto) y en su remate con que se unia a las paredes de levante otra gran pieza que así mismo era capaz para iglesia de un mediano pueblo. Las dos piezas parece haver sido iglesia por la elevacion de su arqueado cimborrio y remate orbicular. La primera está cortada con un paredon moderno que haze mas dificil el conocimiento de lo que fue; la segunda esta muy adornada de pinturas modernas y bastas y porque se va desplomando la boveda aunque detenida algo de los arcos no se dexa registrar a la curiosidad; lo que se adv(i)erte es que a cada lado tiene una escalera muy llana que va subiendo hasta un descanso de mas de 30 pies que era tal vez tribunas y dan la buelta por lo que se cree era el Altar. Puede ser fuese la antigua Cathedral y antes la Mesquita Mayor. Sea lo que fuere en la capilla Real mandó el Rey de Aragón Don Pedro fundar tres capellanias y aún lo encarga a su heredero, en su testamento hecho en Figueras a 21 de agosto de $1385^{56}$

d): En lo mas elevado del monte es donde se hallan los edificios mas viejos del castillo, en donde hay un trozo de claustro de mas antiguedad que el resto de las obras. Allí hay una iglesia que sirve de pieza de horno, y seguramente seria la primitiva, despues de la conquista. En esta misma parte de la fortaleza está el que se supone palacio de los Reyes, y que yo. no me separo de que esto sea cierto. La pieza que sirve de almacen de fuerzas esta pintada de un modo tan grosero que no dudo sea de lo primitivo. La fortaleza lo es por naturaleza, pero en lo demas se halla absolutamente destruida y en el peor estado ${ }^{57}$.

Los cuatro párrafos que acabamos de transcribir, aluden al castillo del rey y tienen el valor de haber sido redactados antes de 1812 , de forma que proporcionan una información ocular de ciertos ámbitos de la fábrica

\footnotetext{
${ }^{56} \mathrm{El}$ párrafo procede del texto más completo conocido de esta obra que se conserva en Lleida: P.J. FINESTRES, Fragmento histórico de la catedral, iglesias y ciudad de Lérida, fol. 46, Lleida, Archivo Capitular, Ms. sin catalogar. El texto que presentamos ya era conocido por haberlo transcrito J. LlADONOSA (La Suda, parroquia de, pp. 41-42).

${ }^{57} \mathrm{~F}$. de ZAMORA, Diario de los viajes, p. 233.
} 
que a raíz de la explosión de ese año, desaparecieron totalmente. Por entonces aún se conservaba o se mantenía el recuerdo de la galería que existió en el ala norte del patio, abierta a los campos, que parece haber comunicado con las habitaciones que desaparecieron al construirse las troneras. Son los cimientos de este sector de habitación lo que ha revelado la campaña arqueológica del año $1992^{58}<$ Fig. 15>. Aunque se alude a esta galeria en tres ocasiones (párrafos " $a ", " b "$ y " $d "$ ) el primer texto, a pesar de las dificultades que se derivan de su lectura, es el más explícito de todos.

Las descripciones también son útiles en lo que respecta a la capilla del castillo. Analizamos este área partiendo de un apriorismo que bien pudiera resultar inexacto: la presencia en Lleida en el momento de redactarse estas notas o de dibujarse los planos a los que venimos aludiendo, de una sola capilla castral. Aunque en este caso nos parece lo más factible, no debe olvidarse, por ejemplo, que en la Aljafería de Zaragoza y en otras residencias contemporáneas existieron dos. Se refieren a la nuestra los párrafos " $c$ " y " $d "$. En el primero, su autor, se manifiesta interesado en identificar exactamente ese ámbito y los términos del redactado hacen sospechar que visitó la Zuda con esa intención. Ahora bien, no resolvió satisfactoriamente sus dudas y por este motivo dejó la cuestión abierta. Como consecuencia, nos ha transmitido una descripción de las dos construcciones que en su opinión podrían haber tenido usos cultuales. Insiste en cada caso en el hecho de que ambos espacios son capaces para acoger "la iglesia de un mediano pueblo". Por la localización que nos da de cada uno de ellos, uno tiene que corresponder al cuerpo que estaba ubicado en el sector oriental del castillo y que desapareció en 1812. Probablemente sea el piso que dividía esta construcción en dos plantas tal como evidencian los planos de $1796<$ Fig. 12 y $13>$ que más tarde comentaremos, lo más aproximado a lo que el cronista, interpreta como "el paredón moderno que la partía". Precisamente la posibilidad de localizar la capilla en esta zona del castillo según sugerencia de P.J. Finestres, debió motivar la distribución de espacios de la fortaleza que propuso en su momento Lladonosa y que se recogió en un plano hipotético que el historiador publicó repetidas veces ${ }^{59}$. La segunda construc-

\footnotetext{
${ }^{58}$ J. UBEDA, Un pati àrab amb una bassa trobat a la Suda, "Diari de Lleida", 10 de novembre de 1992 (artículo periodístico redactado a partir de la información proporcionada por A. Loriente, directora de los trabajos).

${ }^{59}$ Véase: J. Lladonosa, La Suda, parroquia, p. 12.
} 
ción factible de ser interpretada como capilla era la que se ubicaba a occidente y que ahora podemos conocer más detalladamente merced a los planos de finales del siglo XVIII <Fig. $11>$. Por entonces aún se conservaban en ella lo que el autor de la descripción identifica como tribunas, hecho que naturalmente puede relacionarse con la noticia referente a la incorporación de una tribuna a la capilla durante el reinado de Pedro el Ceremonioso ${ }^{60}$. Aunque sustancialmente el texto " $d "$ añade poco más al tema, proporciona una aclaración que no podemos pasar por alto. Cuando Zamora se refiere a la capilla (a él no se le plantean dudas al respecto), dice: "hay una iglesia que sirve de pieza de horno". Esta precisión es muy importante porque el único lugar donde existía un horno según revelan los planos de 1796 es la construcción levantada a occidente que conviene perfectamente por sus características a usos religiosos. No parece, en consecuencia, que queden dudas al respecto. En el siglo XVIII existía una sola capilla y se hallaba en el ala oeste.

El párrafo " $a$ " nos informa también sobre la solución adoptada en las cubiertas exteriores de las salas góticas. Menciona la existencia de terrados planos cubiertos con losas, lo cual convertía estos espacios en excelentes atalayas <Fig. $10>^{61}$. También es interesante la alusión a las torres, a pesar de que no acaba de quedar claro a cuales se refiere. Especula con el hecho de que debería haber cuatro (una por ángulo del castillo) pero registra que entonces quedaban dos. La noticia es un poco sorprendente puesto que, en su recuento, el cronista parece considerar únicamente los baluartes localizados en los ángulos y desecha, en cambio, las torres de flanqueo que alternaban con éstos.

Finalmente es importante que nos hagamos eco de las referencias a pinturas murales que incluyen los apartados " $a$ " y " $d$ ". El primero de ellos señala la presencia de "pinturas modernas y bastas" en la construcción que forzosamente hay que identificar con la capilla.

En el caso de Zamora, en cambio, leemos: "la pieza que sirve de almacen de fuerzas esta píntada de un modo tan grosero que no dudo sea de lo primitivo". Este último ámbito no puede ser más que uno de los dos cuerpos de planta rectangular localizados a oriente del recinto, perdidos ambos también en la actualidad. Si contraponemos el texto de Zamora con

\footnotetext{
${ }^{60}$ Remitimos a la nota 44 y a las referencias correspondientes que allí se recogen.

${ }^{61}$ Véase más adelante la nota 9.
} 
el plano general de la Zuda que inmediatamente comentaremos, existen dos únicos lugares identificados en términos similares. Uno de ellos corresponde a la construcción de planta rectangular y dos pisos de altura (una estructura que, en definitiva, puede identificarse con el donjon francés) conocida como Torre dels Jueus que entonces según revela el plano estaba destinada a almacén de polvora ${ }^{62}<$ Figs. 12 y $13>$. Lo que Zamora debió ver fue algún resto de la pintura mural (forzosamente de temática profana) ${ }^{63}$ que debió embellecer los muros interiores de este ámbito de uso privado.

Hasta aquí hemos analizado las descripciones que, con mayor o menor detalle, aluden al edificio. Ahora debemos detenernos en una fuente que en este progresivo descubrimiento del castillo de Lleida resulta capital: la serie de planos y secciones confeccionados en su mayor parte por un ingeniero militar anónimo en 1796 y fechados a 30 de abril de ese año, excepción hecha de uno de ellos que repite el plano general y una vista exterior del recinto, firmado por el capitán del cuerpo Don Francisco Arajol, a 20 de abril de 1849, posterior, por tanto, a la explosión de 1812. Los originales se custodian en el Archivo Histórico Militar, en Madrid, y hay un total de doce, de los cuales cinco son copia repetida ${ }^{64}$. El material planimétrico que podemos emplear se reduce a seis ejemplares. Se trata de un plano general del recinto $<$ Fig. $8>$ y de una serie de secciones que corresponden a cada una de las zonas contempladas en el primero. Existe la longitudinal y la transversal de las salas emplazadas al sur $<$ Figs 9 y 10$\rangle$, la longitudinal de la construcción erigida al oeste $<$ Fig. $11>$ y en lo concerniente al sector oriental del recinto contamos con otras dos secciones $<$ Figs. 12 y $13>$. Siendo posible, como lo es, contrastar los planos de 1796 con el de 1849 puede evaluarse con todo detalle de que forma repercutió en la fábrica la explosión de 1812. Es suficiente una simple observación de los dos planos generales para advertir como fue arrasada toda

\footnotetext{
${ }^{62}$ A pesar de haber sido habilitada como tal en 1796 ("en el Almacen de polvora se pusieron estantes para doblar el número de barriles sobre los cinco de altura que deven colocarse en su pavimento: se ha entarimado y revestido de madera hasta la altura de dichos estantes", se lee en las observaciones que acompañan el plano general del recinto confeccionado entonces), debemos advertir que tales modificaciones que habrían impedido observar adecuadamente los restos de pinturas existentes en el piso bajo, son posteriores a la visita de Zamora.

${ }^{63}$ Sobre la presencia de estas pinturas de carácter profano en las residencias señoriales del período medieval (sean o no castillos), remitimos a un trabajo sobre las conservadas en la torre de Alcañíz donde tratamos también aspectos generales: F. ESPAÑOL BELTRAN, Las pinturas murales del castillo de Alcañíz (en prensa).

${ }^{64}$ Véase la nota 7.
} 
el área oriental del recinto, aquella que alojaba precisamente el almacén de polvora.

\section{ESTADO DEL CASTILLO REAL DE LLEIDA EN EL SIGLO XVIII. EVALUACIÓN DE SU FÁBRICA A PARTIR DE LAS DESCRIPCIONES Y LOS PLANOS DE 1796}

Si las fuentes escritas han permitido determinar con cierta seguridad la ubicación de la capilla que existió en el interior del recinto desde mediados del siglo XIV, los planos confirman definitivamente tal interpretación. El sector occidental del nivel más alto de la Roca Sobirana < Fig. $11>$ lo ocupaba una edificación de planta rectangular cubierta por dos tramos de bóveda de crucería, más un tercero emplazado en el extremo norte de la construcción que presentaba un cimborrio sobre trompas < Fig. $7>$. Este último es muy similar al que existe en la catedral aunque de formato mucho más simple. Esta construcción albergaba en 1796 un horno de pan perfectamente visible en el plano general del recinto. Es el que menciona expresamente Francisco de Zamora en su descripción. Recordemos que lo ubica dentro de lo que él considera la antigua capilla del castillo. Con estos precedentes, hasta es posible sugerir que la estructura elevada de madera localizada en el tramo previo al cimborrio (emplazado este último forzosamente sobre el presbiterio) y visible en el plano referido, puede corresponder a la tribuna proyectada por Pedro el Ceremonioso en los años finales de su reinado, tribuna a la que se alude en las antiguas descripciones de este ámbito ( párrafo " $c$ ").

Evidentemente, cuando se realizaron los planos que nos sirven de guía, el castillo ya hacía tiempo que había perdido su antiguo carácter real y la fábrica primitiva había sido objeto de modificaciones radicales. En lo que corresponde a la capilla, una intervención que tiene que datar al menos del siglo XVII la afectó muy directamente. El primer acceso al recinto localizado a oriente, al que deberemos aludir más adelante, se trasladó a occidente. Se emplazó en el sector donde se hallaba la capilla y para acomodar esta reforma se inutilizó uno de los tramos de la misma (que quedó aislado de los dos restantes mediante un muro). Finalmente, la puerta exterior se abrió en el lienzo de muralla correspondiente. Esta reforma, es perfectamente evidente en el plano y sección de esta zona y confirma la verosimilitud del grabado presidido por San Anastasio con el que se inicia 
el Llibre Vert Major del Archivo Municipal de Lleida. En él aparece como fondo la Roca Sobirana con el castillo del rey, y en el sector occidental de su muralla la puerta a que aludimos. El grabado ya fue invocado por $\mathrm{J}$. Lladonosa al tratar sobre la Zuda y en particular sobre esta zona de la misma $^{65}$.

Los planos proporcionan otra información de gran importancia en lo referente al ala oriental. Por el hecho de haber acusado más que cualquier otra zona los efectos de la explosión de 1812, este área ha sido en parte una incógnita hasta ahora ${ }^{66}$ pues, como mucho, se contaba con el material recogido en el Atlas < Figs. 1 y $2>$. Hoy sabemos que la ocupaban dos vigorosas construcciones independientes y no alineadas entre sí a nivel de fachadas exteriores, una y otra de planta rectangular y dos pisos de alto $<$ Figs. 11 y $12>$. La más cercana al ángulo noreste, tenía la planta baja dividida en dos ámbitos de dimensiones diversas. Ambos espacios que todo hace pensar se cubrieron con sendas bóvedas de cañón (una de perfil más apuntado y la otra de medio punto), parecen haber estado absolutamente aislados el uno del otro. El acceso a uno de ellos se localizaba en el patio central del recinto, mientras que el del otro se abría a un patio más reducido emplazado entre este cuerpo rectangular que ahora analizamos y el que pasaremos a comentar inmediatamente. Si contrastamos lo que nos dice este material planimétrico con los resultados de la excavación de 1986, es evidente que la habitación abierta al patio central corresponde al corredor a través del cual se accedía a la fortaleza ${ }^{67}$.

Se llegaba al piso superior de esta construcción a través de una magnífica escalera que nacía del patio menor referido. La sala se cubría, según podemos deducir por el dibujo, por medio de una bóveda de cañón seguido, probablemente apuntado. Es importante hacer notar la presencia de

\footnotetext{
${ }^{65}$ J. LladONOSA, La Suda, parroquia, p. 41, fig. s.n.

${ }^{66}$ Aunque la Torre dels Jueus ya era conocida por otros planos recogido en el Atlas de Lleida la información que han proporcionado los de 1796 es esencial para conocer su distribución interior.

${ }^{67}$ J. MARKALAIN I TORRES, op. cit. p. 72. En lo que concierne a la entrada al recinto parece que la descripción que dan de ella los arqueólogos se acomoda a lo que se ha definido como puerta en recodo, característica de la arquitectura militar musulmana [L. TORRES BALBÁS, Puertas en recodo en la arquitectura militar hispano-musulmana, "Al-Andalus", XXV (1960) pp. 419-441]. Según J. Markalain (op. cit. p. 72) la entrada al castillo (traducimos): se presenta en dirección este-oeste, flanqueada por dos muros que conservan parte del enlosado original, para irse estrechando posteriormente al ir avanzando hacia el patio, hasta llegar a su extremo donde gira hacia la derecha tomando la dirección sur-norte.
} 
una línea sobre el nivel de las ventanas que puede corresponder a la de impostas. Por las características de esta edificación es posible aventurar cual fue su proceso de obra. La diferencia existente entre los perfiles de las bóvedas de la planta baja, y el hecho de que ambos espacios hayan tenido accesos independientes, es importante en esta evaluación. Probablemente estamos ante una fábrica fruto de dos momentos de obra diferenciados. $\mathrm{Al}$ primero debe de corresponder la habitación más amplia del piso inferior cuya bóveda, por el formato que adopta (medio punto), parece ser anterior a la que cubre el segundo espacio. Un problema en relación a esta hipótesis lo constituye la diferencia de grosor existente entre el muro exterior que soporta el empuje de la primera y el muro intermedio en el que recayó conjuntamente el de las dos, pero esto puede obedecer a un simple refuerzo de este último, con el fin de garantizar la estabilidad de la construcción una vez ampliada. El formato que presenta este cuerpo con su innegable y potente apariencia militar (obsérvense la falta de aberturas en el muro exterior) recuerda el de los donjons y lo propio puede afirmarse del edificio que trataremos inmediatamente.

Nos hallamos de nuevo frente a una construcción de planta rectangular y dos pisos de alto, que en este caso parece haber sido fruto de un único momento de obra. La planta baja se cubría con una bóveda apuntada $^{68}$ y su entrada estaba en el muro occidental. El segundo piso era uno de los espacios más suntuosos de toda la fortaleza. Es quizá uno de los que reclama con más razón el apelativo de palacio $^{69}$, al menos en el último estadio de ocupación del monumento por parte de la monarquía. Este ámbito se cubría con dos tramos de bóveda de crucería y se iluminaba mediante una elegante ventana abierta en el muro occidental con vistas al patio interior. La

\footnotetext{
${ }^{68}$ La solución adoptada es equiparable a la que hallamos en un molino construido en Albió (Segarra) en la cuenca del rio Corp. En este caso, se trata de una torre de tres pisos de altura de base rectangular. El inferior, que corresponde a un momento de obra anterior a los dos restantes, se cubre con bóveda de cañón apuntado. El que sigue presenta un techo plano de madera cuyas vigas apoyan sobre una gran arcada dispuesta transversalmente respecto a los muros exteriores. El piso más alto se cubre de nuevo con una cubierta plana cuyas vigas descansan en este caso sobre dos arcos apuntados que arrancan de una columna central. La orientación de éstos es longitudinal. F. ESPAÑOL BERTRAN, Els casals de molins medievals a les comarques tarragonines. Contribució a l'estudi de la seva morfologia arquitectònica, "Acta Historica et Archaeologica Mediaevalia", I (1980), pp. 240-245, figs. 5 a 10. Aunque en el momento de redactar ese trabajo me decante por situar la ampliación del molino a caballo de los años finales del siglo XIII y los iniciales del XIV, pienso ahora que su cronología debe llevarse más hacia mediados del Trescientos.

${ }^{69}$ Véase la nota 17.
} 
adornaban dos columnas que identifican sin ningun género de dudas su tipología y origen. Se trataba de un tipo de ventana que se fabricó de forma seriada en Girona y que fue muy frecuente en los edificios catalanes civiles de los siglos XIV y XV; sabemos, ademas, que Pedro el Ceremoniosos lo incorporó regularmente a sus residencias (Valencia, Barcelona etc.) ${ }^{70}$. El aceso se resolvía por medio de una nueva escalera monumental que ascendia desde el patio menor.

La morfología de esta construcción hace pensar en un período de obra avanzado dentro de la historia de la fortaleza y es especialmente significativa en este sentido la organización del espacio en la planta noble. Es en vista a ello que puede sugerirse un momento dentro del siglo XIV avanzado para su erección, análisis que, por otro lado, parece coincidir con las noticias documentales que se refieren a ella, ya que parece haberse construido, a partir de 1366, coincidiendo con la guerra con Castilla. Se trata de la Torre dels Jueus, a la que aluden numerosos historiadores leridanos y que se conoce con este apelativo porque fue este colectivo quien financió la obra a partir de la fecha referida ${ }^{71}$.

Aunque la torre, como hemos visto, se edificó durante el siglo XIV, no podemos pasar por alto su localización dentro del conjunto militar. Su situación en relación al recinto en general es avanzada. En realidad parece ocupar el sitio que podría haberse reservado a una torre albarrana ${ }^{72}$. La Zuda en época bajomedieval, como hemos ido observando, se adaptó a los nuevos preceptos de la arquitectura militar (un progresivo abandono de la austeridad inicial a favor de una arquitectura más genuinamente señorial) y el donjon que comentamos es, entre otras dependencias levantadas entonces, buen testimonio de ello. Resulta por lo tanto perfectamente viable, sospechar que en ese lugar pudo llevarse a cabo una sustitución de este género. El aspecto de la nueva fábrica dentro del conjunto de la fortaleza era imponente ya que su altura superaba considerablemente la de las construcciones

\footnotetext{
${ }^{70}$ Se han publicado diversas notícias documentales sobre este tipo de de producción seriada, valga como ejemplo la que alude a ella en relación al palacio real de Valencia: A. RUBIó i LLUCH, Documents per l'historia, II, p. 75, doc. LXXIV. Para unas reflexiones sobre el tema: J. YARZA, F. EsPañol, Diseño, modelo y producción industrial en la Edad Media, en: El diseño en España. Antecedentes históricos y realidad actual, s.1. 1985, pp. 27-31.

${ }^{71}$ Véanse las notas 51,52 y 53.

${ }^{72}$ Sobre la denominada torre albarrana y su función: L. VILLENA, Sobre la terminología comparada de los elementos fortificativos, "II Congreso de Arqueología Medieval Española", II Comunicaciones, Madrid, 1987, p. 312, fig. p. 314.
} 
inmediatas.

El sector sur del recinto, único ámbito de todo el conjunto del que conservamos vestigios monumentales reseñables, se prolongaba bastante más hacía el este de lo que hoy en día puede parecer < Figs. 8 y $9>$. Ha desaparecido una superficie que equivalía a más de la mitad del espacio que hoy se conserva. Es forzoso sospechar nuevamente que la causa fue la explosión de 1812 y lo confirma el plano levantado en 1849. Lo que quedó en pie siguió en manos de los militares utilizándose como albergue de la tropa. El espacio interior, unitario en origen, se dividió entonces en dos y se mantuvo esta distribución hasta unos pocos años despues de la guerra civil española. Al igual que sucedió con la catedral, un dormitorio destinado a los soldados ocupaba la zona alta inmediata a las bóvedas. Fotografías realizadas entonces lo confirman < Fig. 5>.

La sala que se localizaba a oriente de toda esta ala longitudinal, y que desapareció, era contigua al patio menor del recinto pero no parece haber contado con acceso directo desde el mismo. Tenía planta rectangular y se hallaba separada del sector más ocidental por un grueso muro, aunque, según confirma la sección correspondiente, parece haber existido una ventana, de dificil datación, entre una y otra zona. Estaba cubierta por una bóveda de crucería de dos tramos. Su exterior era plano y puede afirmarse que existía una natural continuidad entre esta terraza < Fig. $11>$ y la que correspondía a la sala inmediata, de dimensiones más amplias.

Esta última aula se ha conservado, aunque muy parcialmente. Se cubría con cuatro tramos de bóveda de crucería de dimensiones desiguales, prueba inequívoca de que la cubierta se adaptó a un espacio construido con anterioridad <Fig. 9>. Esto es incontestable porque, como los muros laterales no se habían previsto inicialmente para suntentar un empuje estructural de ese calibre, hubo que reforzarlos y aún así la cubierta acabó desplomándose. Si el análisis de la morfología de estos muros en los que aún se descubre el inicio de los arcos de las bóvedas resulta imprescindible para fijar el proceso constructivo de este ámbito, también lo son los sillares de las antiguas bóvedas (nervios, claves...) custodiados en el deposito lapidario del monumento.

En el muro exterior de esta sala que corresponde a la muralla de la fortaleza se conservan las dos únicas torres que han subsistido del antiguo recinto. Gracias a una de las secciones realizadas de esta ala en 1796, es posible comprobar la estructura interior de alguna de ellas y apreciar como conectaban con el adarve de la muralla. Esto último es importante puesto que 
se ha perdido el nivel más alto de las paredes y la antigua planimetría resulta la única fuente con que contamos para determinar cual fue la solución adoptada en este punto. En uno de los dibujos, por ejemplo, se incluye la sección de una de las cuatro torres situadas en el lado sur, en concreto la más oriental de todas ellas, hoy desaparecida $\langle$ Fig. 12$\rangle$. Se trataba de una torre de flanqueo y en lo más alto de la misma parece haber existido un paso conectado al camino de ronda. En lo que respecta a su altura era similar a la de uno de los dos bastiones orientales del conjunto (el más antiguo). Aunque la torre estaba distribuida en una serie de pisos, algunos de ellos por lo que parece cubiertos con bóveda, la directa observación de las torres conservadas hoy en día en este lienzo de muralla, lleva a pensar que el interior de las mismas pudo ser inicialmente mucho más simple y que tales bóvedas se incorporaron en un momento posterior a su construcción. Para la reforma a la que aludimos, como trataremos de desarrollar en el apartado siguiente, puede aventurarse una cronología aproximada.

\section{El CASTILlO REAL DE LLEIDA EN ÉPOCA MEDIEVAL: PROCESO DE LA OBRA}

Como se ha visto, la documentación, delimita una serie de momentos entre los años iniciales del siglo XIII y últimos del XIV, durante los cuales se intervino activamente en la fábrica del castillo. No voy a entrar en lo que pueden ser restos musulmanes en la construcción medieval y dejaré también de lado el análisis de supuestas estructuras anteriores al siglo XIII. En realidad, a partir del análisis de la moŕfología arquitectónica y sin apriorismos de ningún género pretendo establecer los sucesivos momentos de obra que registran las construcciones emplazadas en el sector sur y occidental del conjunto. Recordemos que ahí se localiza lo único que resta en pié de toda la fortaleza (ámbito sur) y que pueden ser tenidos en cuenta unos documentos fotográficos anteriores al derrumbe de la zona occidental para este otro sector. La información que proporciona la serie de fotografías realizada a principios de siglo es muy valiosa puesto que recoge el estado y formato de los paramentos exteriores inmediatos al patio central del castillo. Naturalmente, en este examen que iniciamos también es imprescindible la planimetría del monumento realizada en el siglo XVIII que hemos presentado en el apartado anterior.

Una de las primeras cuestiones a considerar, básica, a mi entender, 
es la presencia a lo largo de la fachada contigua al patio central del sector suroeste de una misma solución plástico-estructural: una serie de arcos formeros adosados al muro, sobre el cual actuan como contrafuertes $<$ Fig. $4>$. Por encima de ellos, limitando en su zona alta la fachada exterior, corre una cornisa adornada con pequeños arcos ciegos trilobulados. La fórmula se prolongaba a lo largo de la zona indicada sin interrupciones ni cambios morfologicos de ningun género. La solución nada tiene que ver en principio con lo ornamental: se instaló una línea de refuerzo a unos muros que habían sido concebidos inicialmente para soportar una cubierta ligera de madera pues era imprescindible para garantizar la estabilidad de las bóvedas de crucería con que se quería reemplazarla. Se acudió a la misma vía seguida en época románica para solucionar este problema: cuando se quisieron incorporar bóvedas a edificios preexistentes que presentaban cubierta de madera, se dobló el grosor de los muros originales por medio de unos arcos dispuestos longitudinalmente a éstos ${ }^{73}$. En Lleida, ocurrió así y los planos demuestran, además, que el grosor incorporado era igual al que tenia el muro primitivo. Por otro lado, lo incontestable de la interpretación que proponemos para justificar este añadido lo confirman otros elementos: la gran sala conservada aún parcialmente en la zona sur presenta este tipo de arcos también en su interior, eso si, de mucho menor grosor. Allí se observa que su función, como ocurre con los exteriores, no sólo consiste en reforzar el muro original, permite mantener también un alto número de vanos para la entrada de luz sin poner en peligro la estabilidad del edificio. Esto sucede porque, como los arranques de los nervios de las bóvedas góticas coinciden con esas zonas donde el muro tiene más anchura, el empuje de las mismas se concentra en los puntos reforzados de la estructura. Que todo este sistema de arcos formeros adosados interior y exteriormente es más moderno que el muro inicial, lo demuestra igualmente el descentramiento de las aberturas existentes en la pared contigua al patio con respecto a los arcos de refuerzo referidos <Figs. 14 y $16>$. Por su formato son contemporáneas dos ventanas y un óculo, situado éste sobre la puerta de entrada que da a la corte central; pues bien, ninguno de los vanos aparece totalmente centrado respecto al añadido porterior. Esto acostumbra a indicar prioridad cronologica de una de las paredes, naturalmente la interior.

\footnotetext{
${ }^{73}$ Es una solución adoptada habitualmente y que dentro del siglo XIII tiene también paralelos reseñables como es el caso de la iglesia de la canónica de Escornalbou, en Tarragona.
} 
Existe un nuevo dato a tener en cuenta. La sala del ala a la que nos venimos refiriendo tuvo que poseer inicialmente una cubierta de madera que más adelante se sustituyó por la bóveda de cruceria organizada mediante tres tramos. Si, como sostenemos, esta última no hubiera sido obra de una reforma posterior, resulta dificil justificar la desigual dimension de cada uno de los sectores, como lo revelan los planos existentes.

En nuestra opinión, todo lo dicho abunda en la hipótesis que hemos expuesto. Ahora bien, si en origen se trató de una sala con cubierta de madera, lo lógico sería pensar que las vigas de la misma apoyaron, o bien directamente sobre el muro, o, en su caso, sobre arcos diafragma, aunque dada la luz total del espacio que tiene la sala parece más probable la segunda posibilidad. Fue así como lo confirma una observación atenta del muro sur inmediato a la muralla exterior. Existen en él huellas incontestables de los antiguos arcos, y también se identifican con absoluta facilidad los refuerzos en forma de ligero contrafuerte que se dispusieron exteriormente en total coincidencia con ellos (uno es perfectamente visible desde el interior de la torre de la muralla que queda en pie en ese sector).

Hay otra cosa más que añadir. Si se parte de esta modificación de la sala que estamos defendiendo, también acaba teniendo sentido la intervención en las torres exteriores de la fortaleza. Lo poco que resta actualmente de las mismas (para las partes perdidas podemos analizar los planos del siglo XIX) permite apreciar que en su interior se dispusieron pequeñas bóvedas. Aprovechando trabajos recientes de consolidación de esa zona, pudimos observar directamente el encaje de estas bovedillas con los muros de la torre. Indudablemente se trata de un elemento añadido a una estructura preexistente (las torres debieron tener en origen pisos de madera) y su razón de ser puede relacionarse con la modificación de la cubierta de la sala. Al sustituir el cierre de madera por un sistema de bóvedas era necesario reforzar el muro contiguo al patio central pero también el exterior inmediato a la muralla. Aunque éste tenía mayor grosor, había que contrarrestar también allí el empuje ejercido por la nueva cubierta y la solución fue incorporar bovedillas a las torres. Se dispusieron paralelas a los muros de la gran sala y pasaron a jugar el papel de arbotantes.

A pesar de todo lo apuntado, la estabilidad que se consiguió imprimir a la estructura reformada de la gran sala fue relativa. Más adelante, en una época que no podemos determinar, hubo que reforzar con unos potentes contrafuertes los arcos formeros del patio y aún así la bóveda acabó desplomándose finalmente. 
Este sector que acabamos de analizar es el de interpretación más compleja por las sucesivas modificaciones que revela. Ahora bien, existe la zona que ocupaba la capilla ubicada en el lado oeste, a la que todavía no hemos aludido. Esta parte se ha perdido. Aunque los recientes trabajos arqueológicos han puesto de manifiesto la existencia de unos cimientos, no vamos a entrar en ellos porque pertenecen a un estadio precedente del edificio y corresponde a la arqueología resolver los problemas que plantean. Sí podemos referirnos, en cambio, a lo que existió allí hasta el siglo XVIII. Nos interesa el edificio que se utilizó como capilla real sin entrar en la problemática que plantean las estructuras previas. La disposición de la capilla no sólo la conocemos por una sección y por el plano general del conjunto de 1796 < Figs. 8 y $11>$, también nos informan sobre ella varias fotografías antiguas. Una corresponde al ángulo suroeste del patio central del castillo < Fig. $4>$, otras dos al exterior de esta misma zona <Figs. 3 y $6>$ y una quinta a los restos de las trompas que eran visibles desde el extremo norte de la capilla (lugar del antiguo presbiterio) cuando ya se había desplomado la cúpula y se había cerrado con un muro el espacio que comunicaba ese ámbito cultual con la nave $<$ Fig. 7$\rangle$. Aunque la planimetría es imprescindible para calibrar la organización de este área, el material fotográfico lo es también para dar solución a ciertos interrogantes, uno de ellos el de la cronología. Al analizar esta construcción uno de los primeros problemas que se plantean es el de dar respuesta satisfactoria a la localización inusual de la capilla, hecho que condiciona la extraña orientación del edicio (norte-sur). Por este motivo hasta que contrastamos las distintas descripciones del siglo XVIII con los planos, se nos presentaron dudas a cerca del uso de este espacio, el más singular de toda la fortaleza ${ }^{74}$. Por este motivo Lladonosa debió desestimar localizar el lugar de culto aquí y se decantó por ubicarlo en el extremo este del ala sur: siendo así, la capilla tenía una orientación más ortodoxa ${ }^{75}$. Seguramente para justificar un emplazamiento como el adoptado pueden invocarse diversas razones, pero una es más convincente que las otras: el espacio ideal para la capilla no debía de estar disponible. Esto no resuelve, sin embargo, otros interrogantes: ¿la capilla estuvo siempre en este lugar?, ¿se optó por esta localización

\footnotetext{
${ }^{74}$ F. Español Bertran, Plànols i perfils, pp. 233-235. También ID., Clients i promotors, p. 219 , donde todavía no teníamos del todo clara la dedicación cultual del edificio y sugeríamos la posibilidad de identificarlo con el aula regia en base a modelos distintos de los occidentales

${ }^{75}$ Véase la nota 59.
} 
porque se pretendía una capilla de gran envergadura y los restantes espacios en torno al patio central estaban ocupados por edificios ya en uso?

Por supuesto, no tenemos respuesta para todos estos interrogantes, pero existen una serie de cuestiones que hay que considerar al hilo del problema. La primera, que en 1212 ya se documenta la existencia de una capilla en el castillo ${ }^{76}$ aunque por varias razones no puede tratarse en modo alguno de la que analizamos. Por un lado, según revela la planimetría, ni la tipología arquitectónica, ni las soluciones adoptadas en la cubierta corresponden a lo que es común en los años iniciales del siglo XIII. Es mucho más tardío. Por otro, la fachada inmediata al patio interior de armas está envuelta en el mismo sistema de arcos formeros de refuerzo que ostenta toda el ala sur. Morfológicamente estos arcos revelan también una cronología más avanzada. En realidad, si hay que buscar paralelos a una estructura arquitectónica tan original como la presente puede invocarse uno: la capilla castral de Solsona ${ }^{77}$, y su construcción en un momento temprano dentro del siglo XIV es un dato a retener < Figs. 19, 20 y $21>$.

De todo lo visto hasta ahora se deduce sobre todo un hecho: el castillo real de Lleida fue objeto de diversas reformas a lo largo del período medieval que acabaron configurando la estructura que pervivió hasta comienzos del siglo XIX y que conocemos con cierto detalle gracias a la planimetría de 1796. Es factible determinar la sucesión de estas reformas, y aunque es más problemático asignarles una cronología precisa, también puede avanzarse algo en este sentido si se toman en consideración no sólo las características morfológicas sino también los datos documentales conocidos. Recordemos que la historiografía le ha venido reconociendo tradicionalmente a Pedro el Ceremonioso un papel relevante en este terreno como promotor. Es indudable que lo tuvo a un cierto nivel, pero la revisión de todo el proceso constructivo del castillo leridano retrasa hasta la época de su abuelo Jaime II la campaña más ambiciosa de reformas del conjunto monumental preexistente.

El castillo de Lleida pasó a depender del conde de Barcelona y del de Urgell, coseñores de la ciudad el año 1149. Desconocemos qué sucedió en los años inmediatos, pero es factible sospechar que pudo ocuparse la Zuda sin que se realizaran intervenciones relevantes sobre la fábrica. A principios

\footnotetext{
${ }^{76}$ Véase la nota 13.

${ }^{77}$ Véanse más adelante las notas 85 y 86.
} 
del siglo XIII, durante el reinado de Pedro el Católico, consta que se emprendieron obras y se documenta por vez primera la capilla castral dedicada a San Pedro. Durante el reinado de Jaime el Conquistador, según la conocida referencia de su crónica, se sustituyó la cubierta de madera de una de las salas del recinto por una bóveda. Aunque el monarca alude a una bóveda, no especifica, como es natural, que se trate de una bóveda de crucería. Remarcamos este extremo porque tradicionalmente la reforma en cuestión se ha venido interpretando alusiva a un sector muy concreto del castillo que ha llegado hasta nosotros: el ala sur. La hipótesis era verosímil a priori porque, como se ha visto, en esta zona se llevó a cabo realmente una sustitución de este tipo. Ahora bien, la reforma que revela este sector no puede corresponder en absoluto a la época del rey Jaime porque en el mismo bloque de modificaciones habría que incluir la construcción de la capilla que ocupa el lado oeste del recinto, (recordemos que el sistema de arcos formeros que circundan el patio y cuya razón de ser ya conocemos, envuelve sin solución de continuidad tanto el ala sur como la oeste). Por lo tanto, lo que queda dentro de él le precede o le es coetáneo. Además, la atribución de este sistema de abovedamiento a la época de Jaime I es inviable por otro motivo. Las claves que cierran esas bóvedas hoy conservadas en el deposito lapidario del monumento, son idénticas a unas que hallamos en la catedral $^{78}<$ Fig. $17 \mathrm{~A}-\mathrm{B}>$. Las decoran lacerías de tipo islámico y es factible atribuirlas en su conjunto a un único taller. En la catedral estas claves se localizan a lo largo de la nave lateral norte, a los pies de la central y de la lateral sur y, extrañamente, también en la bóveda del transepto norte junto a la puerta de San Bartolomé ${ }^{79}$. Indudablemente la ubicación de estas piezas en la zona más tardía de un edificio de cronología conocida, proporciona un elemento de referencia importante para fechar la reforma de la cubierta de la sala del ala sur del castillo ${ }^{80}$.

Si continuamos con la catedral, hay otros dos detalles a considerar: la coincidencia existente, por un lado, entre el formato exterior de las

\footnotetext{
${ }^{78}$ Las publica J. BERgós, L'escultura a la Seu Vella de Lleida, Barcelona, 1935, fig. 10.

${ }^{79}$ Para su localización Ibidem, p. 343 y fig. 22.

${ }^{80}$ Sobre la cronología de la catedral leridana véanse las últimas aportaciones de I. BANGO Tonviso, La catedral vieja de Lleida. De la actualización de una vieja tipología templaria, conservadurismos y manierismos de su fábrica, "Congrés de la Seu Vella", pp. 29-37. También para situar la cronología de las zonas más antiguas del edificio J. YARZA LUACES, Primeros talleres de escultura en la Seu Vella, "Congrés de la Seu Vella", pp. 39-53. También F. ESPAÑOL BERTRAN, La catedral de Lleida: arquitectura, p. 191 y ss.
} 

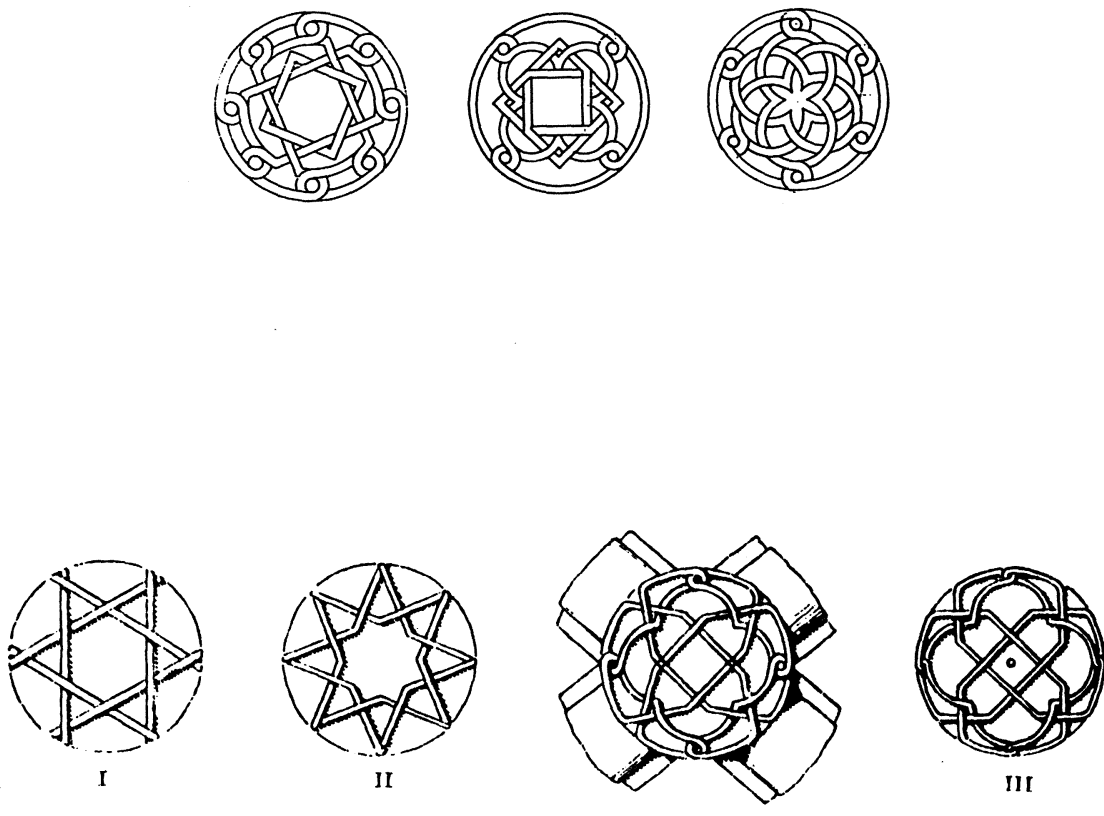

IV

Fig. 17 A. Claves de bóveda de la sala del sector sur. Castillo de Lleida (Dibujo J.F. Ràfols).- Fig. 17 B. Claves de la catedral románica de Lleida (tomado de J. Bergós, L'escultura a la catedral). 
ventanas abiertas en el cimborrio de la seo $<$ Fig. $18>$ y las que aparecen en esta sala del ala sur del castillo que tratamos <Fig. 16> y, además, la presencia de un motivo plástico similar en la cornisa que recorre este mismo cimborrio en su zona más alta y en lo más elevado del sistema de arcos de refuerzo del patio del castillo. Se trata de una cornisa en la que unos arquitos ciegos trilobulados descansan sobre ménsulas anicónicas <Fig. 4>. Además, el cimborrio del castillo no dejaba de presentar analogías con el que todavía se conserva en otro edificio de la zona: la iglesia de Tamarite de Litera.

En mi opinión estas coincidencias no pueden señalar más que en una dirección: ciertas partes de la catedral fueron coetáneas a otras zonas del castillo del rey y todo nos lleva a situar estạs reformas en los años iniciales del siglo XIV y en época de Jaime II. Al menos puede atribuirse a este período la remodelación de la sala sur con el añadido de las bóvedas que obligó a reforzar toda la estructura tanto desde el lado de la muralla (abovedamiento de los pisos de las torres de flanqueo) como desde el interior del patio (incorporación del sistema de arcos formeros). Probablemente entonces pudo construirse la capilla cuya fábrica, como hemos sostenido, parece obligado sospechar precede a los arcos formeros también adosados a esa zona. Por supuesto es factible justificar estas coincidencias entre la catedral y el castillo en base a la dirección conjunta de los trabajos por parte de los miembros de la familia Prenafeta, según hemos visto en un capitulo anterior.

En lo que concierne a la capilla, la edificación de la misma debió suponer un cambio de ubicación del espacio cultual dentro del castillo ${ }^{81}$. Según confirman otros proyectos reales contemporáneos (palacios de Barcelona, Valencia etc.), Jaime II imprimió una nueva valoración de este ámbito dentro de sus residencias reales ${ }^{82}$, pero, en Lleida, para favorecer la monumentalización deseada, debio hacerse necesario disponer de un solar de dimensiones mayores al originario. Ignoramos qué existió previamente en el ala oeste, pero hubo de sacrificarse para ubicar en ella la proyectada capilla. Se levanto, por lo tanto, un edificio extremadamente original $<$ Fig. $11>$ de planta rectangular y tres tramos, los dos primeros cubiertos por

\footnotetext{
${ }^{81}$ Las dimensiones habituales en contraste con el formato adoptado en Lleida son un buen argumento. Véase más adelante la nota 93.

${ }^{82}$ Desarrollamos este aspecto en el apartado VI del estudio.
} 
sendas bóvedas de crucería, el último, correspondiente al presbiterio, por un cimborrio sobre trompas ${ }^{83}$. Uno de los rasgos más originales de la construcción lo es sin duda la presencia de este cimborrio sobre un presbiterio plano. Aunque se trata de una rareza, recuerda soluciones usuales en ámbito sevillano donde las cabeceras cuadradas cubiertas con bóvedas sobre trompas se han puesto en relación con el modelo de qubba islámico ${ }^{84}$. En Cataluña, puede invocarse la capilla del castillo de Solsona como paralelo ${ }^{85}<$ Figs. 19, 20 y $21>$. Erigida, según parece desprenderse de la documentación y de su propia morfología arquitectónica, a principios del siglo $\mathrm{XIV}^{86}$, confirma la circulación por la Cataluña del primer Trescientos de una tipología circunscrita por lo que sabemos hasta ahora a ambientes castrales y a la que pueden adscribirse los dos ejemplares censados. La solución resulta muy ajena a la que se adoptó por esos mismos años en el castillo real de Barcelona, de naturaleza mucho más funcional ${ }^{87}$. Para situar

\footnotetext{
${ }^{83}$ Elemento habitual en edificios levantados a lo largo del siglo XIII en Cataluña como lo son las catedrales de Tarragona y Lleida, la iglesia del monasterio de Vallbona de les Monges, la de Sant Cugat del Vallés y, ya en la provincia de Huesca, la de Tamarite de Litera.

${ }^{84}$ Soluciones arquitectónicas cercanas a la leridana las hallamos dentro de un área del mudejar sevillano (el Aljarafe). Cf. D. ANGULo, Arquitectura mudejar sevillana de los siglos XIII, XIV, y XV, Sevilla, 1932 y, más recientemente A.J. MORALES, Reflexiones sobre algunas iglesias mudéjares del Aljarafe sevillano, Mudejar Iberoamericano, Granada, 1993, pp.39-54 (agradezco a A. Morales la indicación de su trabajo al respecto de este tema). Como ejemplo cercano al leridano podemos señalar el caso de la capilla del castillo de Alcalá de Guadaira, un edificio de planta rectangular que cubre el presbiterio plano con una cúpula. Véase L. TORRES BALBÁS, 1981, Dos obras de Arquitectura almohade: la mezquita de Cuatro Habitan y el castillo de Alcalá de Guadaira en Id.. Obra dispersa I. Al-Andalus, Madrid, 1987, pp. 282288. Esta especial tipología se ha puesto en relación.

${ }^{85} \mathrm{Se}$ trata de un edificio de planta rectangular con dos tramos cubiertos por bóveda de crucería, más un tercero, el que corresponde al presbiterio, que lo está por una cúpula sobre trompas. En todo ello existe un dato a reseñar: los arcos arrancan de unos pilares coronados por pequeños capiteles en los que se hace uso de un repertorio ornamental mediocre, que está, sin embargo, en la línea de lo que se ha definido como escuela de Lleida. Se trata de un tipo de elementos decorativos tanto vegetales como geométricos que se divulga por una serie de edificios muy retardatarios dentro del románico en la zona inmediata a Lleida y que parecen depender más o menos lejanamente de la catedral. Para ello F. FITÉ I LLEVOT, Escultura tardana: les portades de la denominada Escola de Lleida, "Congrés de la Seu Vella", pp. 77. 91 .

${ }^{86}$ Para la capilla del Castellvell de Solsona dedicada a San Miquel A. Llorens I SolÉ, Solsona $i$ el Solsonés en la historia de Catalunya, I, Lleida, s.a., pp. 219-221. Según las notícias que aporta el historiador, la capilla y el resto de la fortaleza se remodelaron durante el gobierno del vizconde de Cardona Ramon Folc X, entre 1310 y 1320 . Es significativa, al respecto, la alusión a propósito del lugar donde se rindió homenaje a los Cardona en 1320: "in castro sive in hospicio novo castri Celsonae" (Ibidem, p. 220). Sobre el edificio, también P. CATALÁ, Solsona i el Castell Vell, en Els Castells Catalans, VI-I, pp. 85-103.

${ }^{87}$ Véase el apartado VI del trabajo.
} 


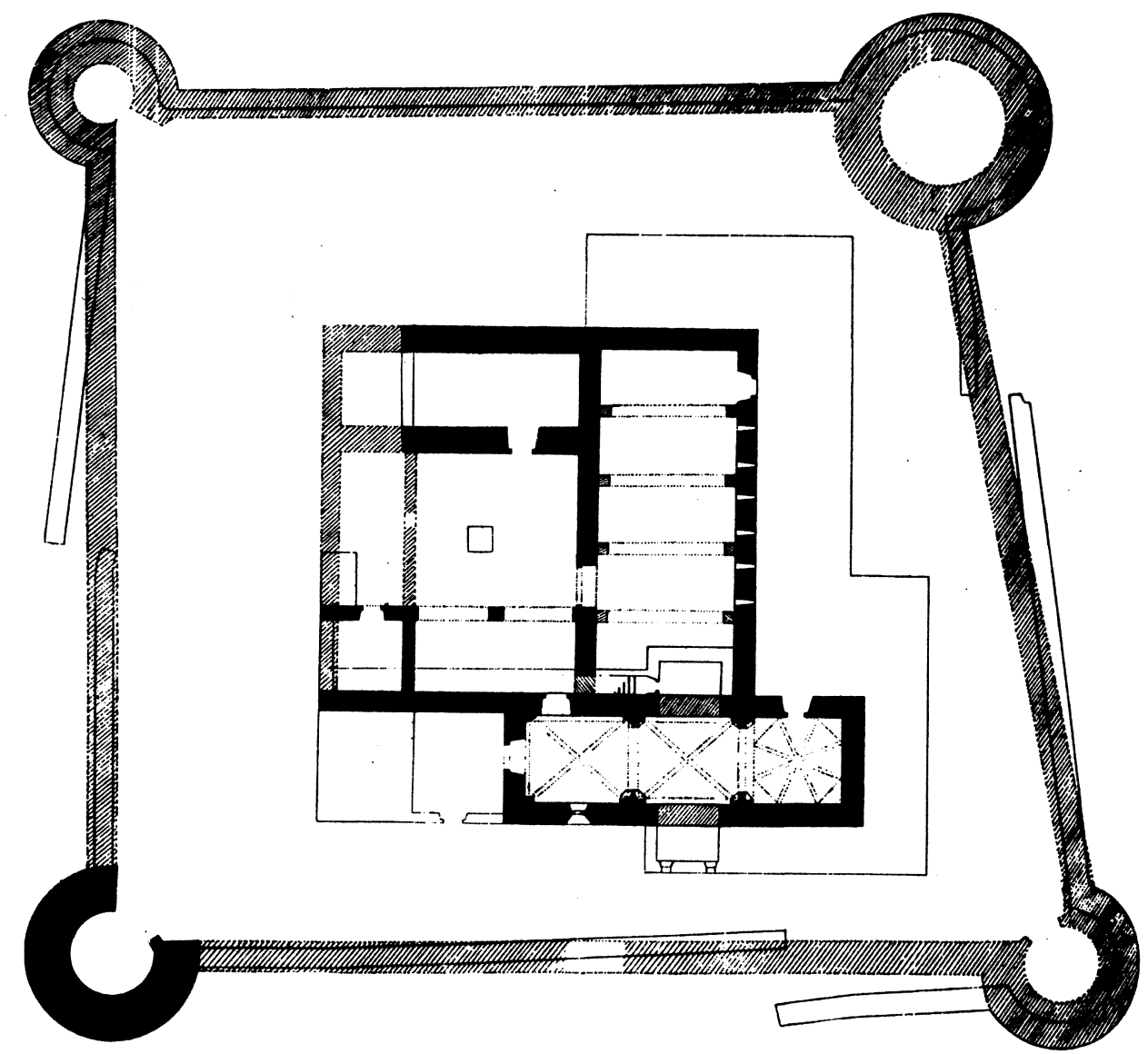

Fig. 19. Plano general del Castellvell de Solsona. 


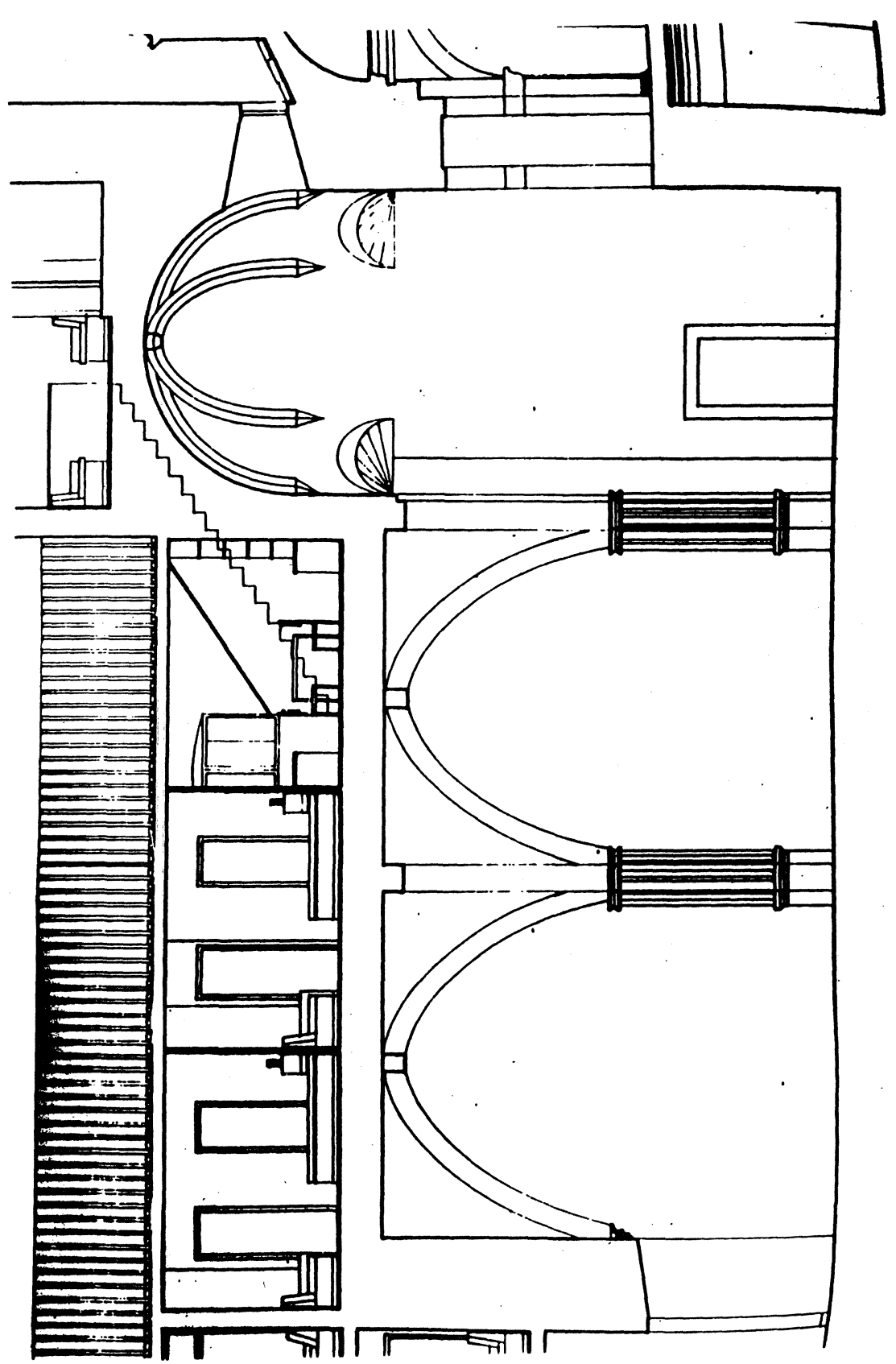
Cuadrench).

Fig. 20. Sección longitudinal de la capilla del Castellvell de Solsona (según Jaume 
la construcción de la capilla de Lleida contamos con una referencia documental importante: la orden a Berenguer de Palau en 1316 sobre la colocación de vidrieras ${ }^{88}$. Aunque la capilla no parece haber tenido ventanas en los tramos de la nave, las hubo en el cimborrio: ocho en total. De ser válida toda nuestra argumentación, la incorporación de estos cierres constituyó el punto final de la obra.

Si como defendemos, las distintas alas que circundan el patio central se reformaron en la época de Jaime II, es obvio que la muralla exterior que las envuelve $<$ Figs. 3 y $8>$ y que hubo que ser reforzada en ciertos lugares para asegurar la estabilidad de los ámbitos modificados, tiene que ser por fuerza más antigua. Esta realidad que nos viene dada por el análisis del proceso de obra, obliga a situar la edificación de la muralla exterior en un periodo indeterminado previo a 1300 , aunque es posible acotar algo más este extremo. En esta línea es importante retomar lo que nos dice la documentación respecto a ese período e invocar las noticias relativas a las obras ejecutadas en el castillo en época de Pedro el Católico y Jaime I que hemos presentado en un capítulo anterior. Todos cuantos han estudiado con mas o menos detalle el castillo real de Lleida han destacado la similitud de su estructura general con la de otras fortalezas, singularmente las de Sádaba y Mequinenza, en Aragón ${ }^{89}<$ Fig. $22>$. En todos estos casos se trata de construcciones vinculadas tipológicamente a la que se ha venido denominando fórmula Felipe Augusto ${ }^{90}$. Como que hasta ahora, en base a la referencia contenida en la crónica real, la fábrica del castillo leridano se situaba en el reinado de Jaime el Conquistador y, más particularmente en los años centrales del mismo, resultaba más tardía que los otros testimonios de su misma tipología. Ahora bien, si se revisa el problema desde la nueva perspectiva que proponemos, las cosas se ponen en su sitio. Las obras iniciales de época cristiana en la fortaleza, parecen haber comenzado en época de Pedro el Católico y continuaron durante la minoría de edad de Jaime I, lo que no impide que pudieran haberse prolongado perfectamente

\footnotetext{
${ }^{88}$ Véase la nota 22.

${ }^{89}$ Para el castillo de Mequinenza, A. FLORENSA, El castillo de Mequinenza y su restauración, Barcelona 1960; también C. GUITART APARICIO, Castillos de Aragón, II, Zaragoza, 1976, pp. 95-98 y para Sádaba, Ibidem, I, 185-191.

${ }^{90}$ Sobre esta tipología en particular, F.GEBELIN, Les chateaux de France, Paris, 1964, pp. 52-58; J. GaRdelles, Les chateaux du Moyen Âge dans la France du Sudouest, Genève-Paris, 1972, pp. 67 y ss. Sobre su incidencia en la Corona de Aragón, véanse los trabajos de C. Guitart Aparicio, Castillos, I, pp. 33-34.
} 

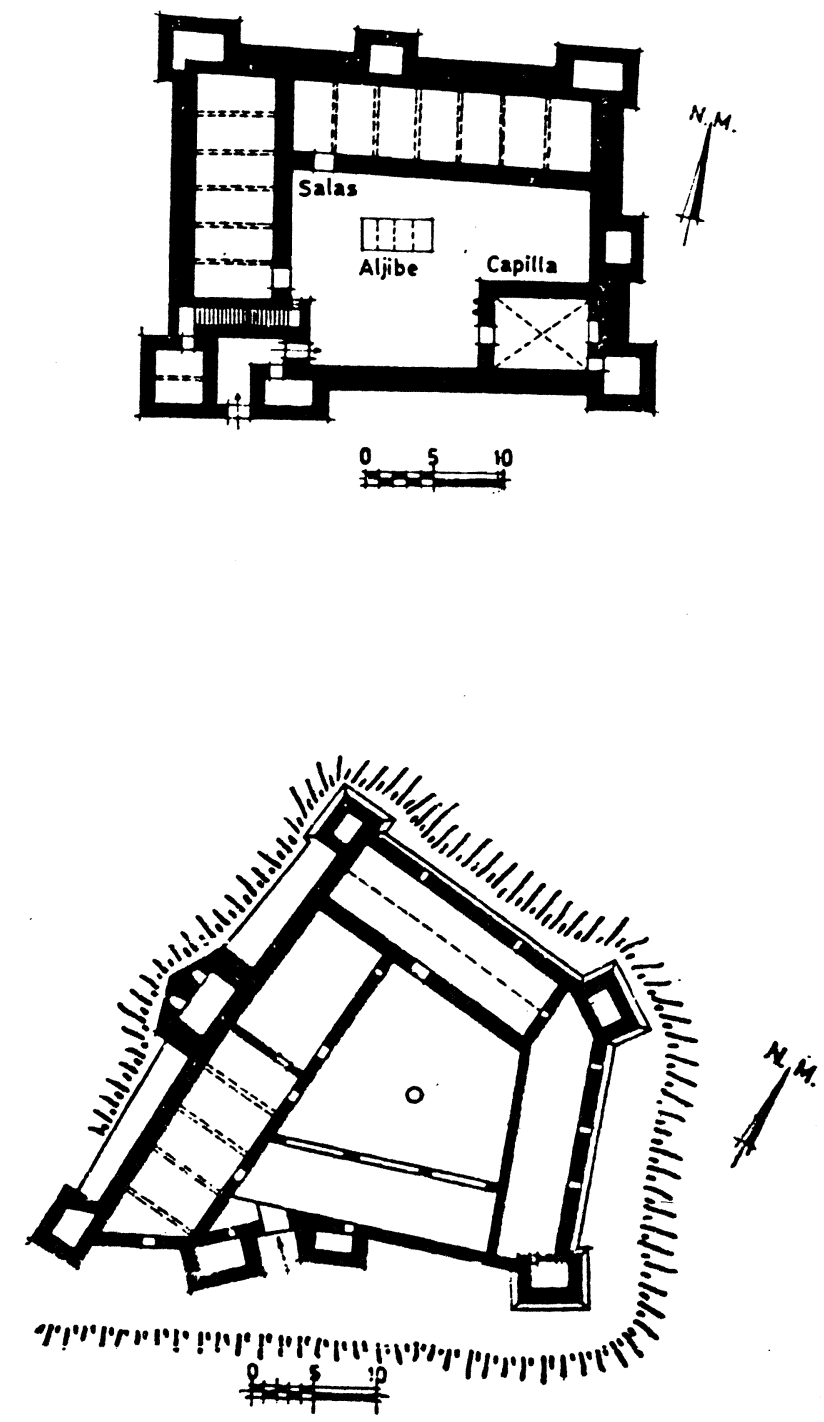

Fig. 22 A. Plano general del castillo de Sádaba.- Fig. 22 B. Plano general del castillo de Mequinenza. 
hasta unos años más tarde. De este modo la tipología arquitectónica encaja perfectamente con el nuevo modelo que parece haber circulado por Cataluña y Aragón a caballo de los siglos XII y XIII. Probablemente entonces se fijo la planta general y se construyeron las distintas alas alrededor al patio central. Al sur, adosada a la muralla, se ubicó una gran sala provista de arcos diafragma y cubierta plana de madera, en la línea que sigue el salon real del palacio de Barcelona ${ }^{91}$. La terraza superior debía funcionar, como en otros casos, a modo de atalaya ${ }^{92}$, conectada a todo el sistema defensivo de la fortaleza del que eran parte sustancial las torres de flanqueo, éstas entonces provistas de diversos pisos de madera. Existía también una capilla que todo hace suponer sería de reducidas dimensiones ${ }^{93}$ y que probablemente estaría orientada al este. Naturalmente las restantes alas situadas alrededor del patio contarían también con habitaciones, pero es dificil pronunciarse al respecto.

Sobre esta estructura inicial se llevaron a cabo las importantes reformas documentadas durante el reinado de Jaime II. Más adelante, en época del Benigno y del Ceremonioso, se realizaron también trabajos que, si se exceptua la Torre dels Jueus, parecen haber afectado más a lo decorativo o a las usuales tareas de conservación que a lo estructural. Se pintaron cámaras interiores, se acomodó una bañera en las habitaciones privadas de la reina, se embelleció la capilla con retablos y se le añadió una tribuna. Naturalmente, pudieron concluirse también obras iniciadas con anterioridad y emprender otras más puntuales que tendrían que ver con la referencia documental de 1336 a la necesidad de un lugar para guardar las herramientas. Sin embargo, no parece que ninguna de estas realizaciones

\footnotetext{
${ }^{91}$ Véase la presencia de estas salas en Sádaba a partir del plano del recinto que publica C. GUITART APARICIO, op. cit., I, p. 186.

${ }^{92}$ Sobre el uso de estas terrazas existen distintas referencias contemporáneas. Es el caso de la Crónica de Jaime el Conquistador cuando se relata como se gestó la conquista de Valencia. El rey dice en ella: "E nós estàvem en nostre regne en Aragó jugant e deportant: e erem en Alcanís, e ab nos lo Maestre de l'Espital e don Blasco d'Alagó" (todo hace pensar, por los acompañantes, que la escena se desarrolla en el castillo de los Hospitalarios), "e foren abdós denant nos en un terrat. E nós estant així deportant e parlant..". (capítulo 127). En otra ocasión, refiere: "E quan haguem sopat pujam-nos en lo terrat del castell de Cullera. E, quan venc que el sol fo post, e açò era en lo temps d'agost, faeren una alimara, e sempre de mantinent faerenne altre, e nós entenem, per la carta que ens havia enviada, que els combatien" (capítulo 312).

${ }^{93}$ Disponemos de un número crecido de paralelos para especular a propósito de las dimensiones de la primitiva, puesto que se trata de recurrir a la solución más genérica en lo que a las capillas castrales se refiere. Así, por ejemplo, la de Sádaba mide 9 por 7 metros. Pueden rastrearse más datos en C. GUITART APARICIO, op. cit.
} 
pueda localizarse en el sector suroeste. Nos queda, eso sí, toda el ala norte de la que aún no hemos hablado.

Según describen dos de las descripciones del siglo XVIII que hemos recogido ${ }^{94}$ y también ha acabado por reveladar la arqueología ${ }^{95}<$ Fig. $15>$, antes de ser arrasada para construir en ella las troneras, existieron allí un conjunto de habitaciones. Desgraciadamente, la información que nos proporciona la planimetría de 1796 para otros sectores nos la escatima en éste, dado que cuando se realizó ya estaban construidas las troneras. Según revelan otros planos más antiguos, esta modificación radical se llevó a cabo hacia $1737^{96}<$ Fig. $2>$. Teniendo en cuenta esto último la descripción de Pere Joan Finestres adquiere toda su dimensión: se trata de los apuntes de alguien que ha visto lo que existía antes de esta transformación radical. Recordemos que nuestro personaje nació en 1691 y murió en el año 1769 en Lleida, ciudad en la que residió gran parte de su vida y donde fue canónigo ${ }^{97}$. Aficionado a las antiguedades de lo que es buen testimonio su proyectado Fragmento histórico de la catedral... , del que hemos extraído los párrafos que comentamos, hubo de visitar el castillo en distintas ocasiones y vió el monumento antes y despues de ser arrasada el ala norte. Solo así se explican los términos que emplea para describirla: "A la parte de Tramontana que es la opuesta a la de dichas torres hay un grande passillo de mas de 200 pasos de largo y poco menos de 100 passos de ancho, según se discurre por los vestigios que quedan corria una (ilegible) de columnillas para sustentar otra galería más baxa igual a los cuartos de la habitación que ya no parece y que se quitó para componer la defensa del castillo a lo moderno, pues en la muralla exterior se abrieron troneras para la artillería". En otra redacción (que puede ser considerada borrador de la anterior) el mismo historiador se refiere nuevamente a la existencia por septentrión (es decir norte) de una galería muy alegre.

Nosotros hemos defendido en otra ocasión la posibilidad de que existiese allí una galería abierta. Dado que la zona norte del recinto era por su situación la que disfrutaba de una mejor defensa natural, no deja de ser

\footnotetext{
${ }^{94}$ Véase más adelante en el texto.

${ }^{95}$ En especial la campaña de 1992 . Véanse las notas 34 y 58.

${ }^{96}$ B. Catllar i Gosa, P. Armengol i Menen, Atlas de, fig. 46.

${ }^{97}$ Sobre nuestro personaje E. CORREDERA, La escuela histórica Avellanense, Lérida, 1971, p. 16 , nota 2 .
} 
verosímil suponer que pudo localizarse en ella una loggia, una galería abierta. Hay que reconocer que el párrafo de Finestres es extraordinariamente confuso, pero la alusión a: "las columnillas para sustentar otra galeria mas baxa igual a los cuartos de la habitación que ya no parece y que se quitó para componer la defensa del castillo a lo moderno" sólo pueden referirse en mi opinión a algo de ese tipo y los innumerables paralelos coetáneos que pueden esgrimirse ${ }^{98}$ son argumento favorable a ello. Además es muy común que en el siglo XVIII se recurra al calificativo muy alegre en referencia a la existencia de una buena perspectiva sobre el paisaje circundante. Naturalmente, de ser correcta toda la interpretación del edificio que hemos venido sosteniendo hasta ahora, el castillo de Lleida (por la tipología que revela) tuvo que estar amurallado en origen también en esta zona norte. Sin embargo, de haber sido así, dificilmente se hubiera hablado de una galería muy alegre, porque el modelo castral supuestamente seguido no contemplaba la existencia de habitaciones ni miradores abiertos hacia el exterior del recinto.

Puede que los planos anteriores al año 1737 aclaren algo este punto. En varios de ellos se advierte todavía la existencia de este sector de habitación. Dos están fechados en $1707^{99}$ y con anterioridad a 1735 el tercero $<$ Fig. $1>$. Si bien los dos primeros confirman la presencia de una construccion de planta rectangular que cerraba el patio de la fortaleza por el norte, el tercero es más preciso: informa de un hecho muy significativo en relación al problema que tratamos. En el ala norte se aprecia una modificación de la debió ser la configuración primitiva del recinto. El modelo castral que se había aplicado en Lleida respondía a un esquema muy preciso que debía mantenerse en la totalidad de la fortaleza: se había delimitado un espacio por medio de una muralla provista de torres de flanqueo y, en su interior, pegadas a ella y circundando el patio central, se situaban las habitaciones. Se trataba pues de una construcción totalmente ajena al exterior. Difícilmente podría haber existido una galeria abierta en un edificio de esas características. En Sádaba y en Mequinenza < Fig. 22> es así. En Lleida, por lo que podemos apreciar en el plano que comentamos, también debió serlo, pero el prototipo fue parcialmente modificado con posterioridad.

\footnotetext{
${ }^{98}$ Son frecuentes en los castillos coetáneos estudiados por M. Durliat en el reino de Mallorca. Cf. M. DuRLiat, L'Art al Regne, pp. 142 y ss.

${ }^{99}$ B. Catllar i Gosa, P. Armengol i Menen, Atlas de Lleida, nums. 28, 30 y 43.
} 
Es el único modo de explicar la existencia con anterioridad a 1735 de lo que parecen torres de flanqueo en una parte del lienzo de muralla norte, torres que no se aprecian en lo restante del muro. Esta realidad es inequívoca y parece forzarnos a una interpretación: un sector de la muralla norte debió modificarse de forma radical, segàndose, con anterioridad a 1735. Esta más que probable intervención en la fábrica que puede haberse realizado en época gótica, a tenor de lo que fue el proceso de obra general de la fortaleza, hace verosímil la existencia de una galería, o de algo parecido a ella en ese lugar.

La Torre dels Jueus <Fig. 13> se ha venido considerando tradicionalmente una obra del siglo XV. Ya hemos visto, sin embargo, que la cronología no es la que conviene a un edificio de sus características, pero, además, existe un dato publicado ya hace tiempo y que ha estado perdido hasta hoy para la historiografía. Se trata de la referencia a la construcción de esta torre durante la guerra contra Castilla ${ }^{100}$. Fra Guillem de Guimerà era quien dirigía las obras de fortificación de la ciudad como lo había hecho en otros lugares de Cataluña ${ }^{101}$, quizá podría corresponderle la paternidad de este soberbio donjon, la última gran empresa constructiva de época medieval dentro del castillo del rey.

\section{LA ZUDA DE LLEIDA EN EL CONTEXTO DE LOS CASTILlOS REALES DE LA CORONA DE ARAGÓN}

En las páginas precedentes hemos intentado fijar las distintas fases constructivas del castillo real de Lleida, así como la filiación de su tipología. En este sentido coincidimos plenamente con aquellos que la han adscrito al modelo Felipe Augusto y creemos que las precisiones cronológicas que acabamos de hacer sobre su fábrica, apoyan esa aproximación. Su planta regularizada, c sn los muros exteriores reforzados por torres de flanqueo y con habitacicn is adosadas a la muralla circundando un patio central, en el interior, responde al ese modelo divulgado por Europa a partir de los últimos años del siglo XII. Fue en su primera época un edificio soberbio que menos de un siglo después de su construcción pudo beneficiarse de una serie de reformas cuya importancia excede el del propio ámbito del castillo. El

\footnotetext{
${ }^{100}$ Véase la nota 51.

${ }^{101}$ Véase la nota 52.
} 
reinado de Jaime II es trascendental en este sentido. En distintas ocasiones ya nos hemos pronunciado a propósito de la decisiva actitud del soberano en el cambio de actitud que va a registrarse en Cataluña alrededor de 1300 en relación a los proyectos artísticos ${ }^{102}$. Como portavoz de la monarquía, Jaime II desde su llegada a Cataluña procedente de Sicilia en 1291, va a emprender una ambiciosa política constructiva o restauradora de sus residencias, que carece de antecedentes en los territorios de la Corona de Aragón, pero que tiene un referente en el caso del efímero reino de Mallorca ${ }^{103}$. En realidad la introducción del gótico corre paralela a este cambio de mentalidad del que no quedará al margen la alta nobleza ${ }^{104}$.

Jaime II construyó nuevas residencias reales ${ }^{105}$ y remodeló otras muchas ${ }^{106}$ destacando entre las últimas las localizadas en las principales ciudades de sus reinos: Barcelona ${ }^{107}$, Tarragona ${ }^{108}$, Tortosa ${ }^{109}$, (y naturalmente Lleida) en Cataluña, en Valencia el denominado Real y en Aragón

\footnotetext{
${ }^{102} \mathrm{~F}$. ESPAÑOL BERTRAN, La escultura gótica funeraria en Cataluña (s. XIV), II, Universidad de Barcelona, 1987, pp. 743 i ss. Id.. Clients $i$ promotors en el gòtic, pp. 217 y ss.

${ }^{103}$ M. DuRliat, L'Art en el Regne, pp. 143-216.

${ }^{104}$ También en su caso se recurrirá a la propia residencia como imagen de poder. Es el caso de los condes de Empùries con Bellcaire (reproducción del castillo de Perpiñán). Sobre esta edificación, P. Català, Castell-Palau de Bellcaire, en Els Castells Catalans, II, Barcelona, 1969, pp. 609-616. También de los Cardona en Solsona. Sobre esta última remitimos a la nota 86.

${ }^{105}$ Es el caso de la de Egea de los Caballeros en Zaragoza, A. SINUÉs RuIZ, La construcción de un palacio real en Egea delos Caballeros, "Estudios de Edad Media de la Corona de Aragón", III (1947-1948), pp. 420-460. También de la de Torruella de Montgrí en Girona, aunque, en este caso, se trataba de una fortaleza de eminente carácter militar, construida exnovo frente al territorio del conde de Empúries. Sobre ella E. MARIATEGUI, Arquitectura militar de la Edad Media en España: Castillo de Torruella de Montgrí (Cataluña), "El Arte de España", VI (1867), pp 143 y ss. F. DE Bofarull, El castillo de Santa Catalina, "Revista de Gerona", XIV (1890), pp. 161-168.

${ }^{106}$ Sobre este particular véase J.E. MARTínez FERRAndo, Jaime II de Aragón. Su vida familiar, I, Barcelona, 1948, pp. 28 y ss. Además de las residencias referenciadas en el trabajo citado, constan reformas en el de Castell-lleó, en el Vall d'Arán, entre 1318 y 1320. Véase: J. REGLÁ CAMPISTOL, Francia, la Corona de Aragón y la frontera pirenáica, Madrid, 1951, I, p. 299, nota 72, vol. II, p. 368 , doc. 77.

${ }^{107}$ Sobre éste A.M. ADROER I TASIS, El Palau Reial Major de Barcelona, Barcelona, 1978, pp. 23 y ss.

${ }^{108}$ Véanse los estudios que siguen: A. ALEGRET, El castell del Rey, "Butlletí Arqueològic de Tarragona", III (1923), pp. 77-80. I. COMPANYS, N. MONTARDIT, El castell del rei en temps de Jaume II, Tarragona 1995.

${ }^{109}$ Sobre el castillo de Tortosa remitimos a la documentación referenciada en P. M. DE BARCELONA, La cultura catalana, "E.F.", 93 (1991).
} 
la Aljafería ${ }^{110}$. Se trataba de edificios preexistentes que resultaban poco cómodos pero, sobre todo, escasamente adecuados a la imagen que el soberano queria transmitir de la monarquía que encarnaba. Sus contactos con otra cultura (la siciliana) y el modelo que le servían desde cerca los reyes de Mallorca tuvieron que influir decisivamente en el cambio que va a operarse. En Jaime II advertimos una voluntad de recurrir a la residencia como emblema áulico y esto se aprecia singularmente en el desarrollo que va a darse a ciertos espacios dentro de ella.

En Lleida, esto se pone de manifiesto a partir de dos ámbitos distintos. Por un lado, a partir del aula regia (el palau al que se refiere un documento de 1316), que creo debe corresponder a la gran sala cubierta con bóvedas de crucería que ocupa el sector sur del recinto y que fue remodelada a comienzos del XIV y, por el otro, a partir de la capilla. Significativamente, esta nueva dimensión otorgada al espacio cultual, es una constante en las principales residencias reales de Jaime II. Con él se construyó la nueva capilla del palacio de Barcelona ${ }^{111}$ y hay que sospechar algo similar en el caso del Real de Valencia si atendemos tanto a la documentación conoci$\mathrm{da}^{112}$ como al impacto que parece haber causado la obra en sus contemporáneos. En este sentido podemos aportar una noticia inédita muy reveladora. En un testamento fechado en 1318, un miembro de la familia Híjar estipula las características que ha de tener la capilla familiar en los Predicadores de Zaragoza en estos términos: "i se faga una capiella a la parte donde es la capiella de Sancha Pérez de Aguilar doy es la vidriera la qual sia feita a forma de la capiella del real de valencia del rei"113. Hay que advertir que la actitud del soberano en este punto no constituye un hecho aislado y lo confirman las residencias erigidas coetáneamente en el reino de Mallorca (singularmente el castillo de Perpiñán) ${ }^{114}$. También la capilla del castillo de Montpellier manifiesta, ya en época de Jaime I, lo que puede ser un

\footnotetext{
${ }^{110}$ Véase J.E. Martínez Ferrando, Nuevos datos sobre el palacio del Real de Valencia, "Boletín de la Sociedad Castellonense de Cultura", 21 (1945) pp. 165-174. Sobre la Aljafería: C. ORCASTEGUI GROS, Precios y salarios de la construcción en Zaragoza en 1301, ("La ciudad hispana durante los siglos XIII al XVI", II), "En la España Medieval", 7 (1985) pp. 1221-1239.

"'Véase la nota 107.

${ }^{112}$ Véase la nota 110.

${ }^{113}$ Daremos a conocer el texto completo en un trabajo que estamos concluyendo sobre iconografía funeraria.

${ }^{114}$ Sobre esto, cf. M. DURLiat, L'Art en el Regne, p. 163 y ss.
} 
importante antecedente, aunque en este último caso se ha esgrimido como modelo el edificio erigido en su palacio parisino por San Luis para servir de receptáculo a las reliquías traídas desde Tierra Santa ${ }^{115}$.

No nos consta que la capilla leridana poseyera reliquias, que fuera, por tanto una de las Saintes Chapelles que proliferaron tanto en ámbito real o nobiliario como episcopal en Francia y otros lugares ${ }^{116}$, pero es indudable que la monumentalización de que fueron objeto las fábricas de muchas capillas castrales a imagen de la de París está en el origen de ese singular tratamiento arquitectónico que acusa. Frente a las reducidas dimensiones de las anteriores, en Cataluña, a comienzos del siglo XIV, se adopta un formato decididamente monumental. Eso sucede no sólo por inciciativa real (recordemos el caso de la del castillo de Bellcaire, residencia de los condes de Empùries), pero sin duda Jaime II fue un decidido impulsor de esa novedad arquitectónica cuya significación excedió abundantemente el territorio de las formas artísticas para pasar al de los conceptos.

\section{RÉSUMÉ}

La vieille Zuda arabe de Lleida est devenue palais royal chrétien après la conquête du site en 1149, mais la forteresse fut entièrement reconstruite pendant le XIIIe siècle selon la typologie de Philippe Auguste. D'autres modifications postérieures appartiennent principalement à l'époque du roi Jacques II (la chapelle, par exemple, l'un des bâtiments les plus intéressants du château) et à la fin du XIV ${ }^{e}$ siècle (le donjon, qu'on appelle Tour des Juifs). Dans cette étude d'après la documentation, planimétrie ancienne et descriptions du monument du XVIII ${ }^{\mathrm{e}}$ siècle, ont analyse le processus de construction du château, conservé en grande partie jusqu'au début du $\mathrm{XIX}^{\mathrm{e}}$ siècle, mais ruineux entièrement après deux explosions des années 1810 et 1936.

\footnotetext{
${ }^{115}$ Ibidem, pp. 154-155. También I. HACKER-SÜCK, La Sainte Chapelle de Paris et les chapelles palatines du Moyen Age en France, "Cahiers Archéologiques", XIII (1962), pp. 217257. También CL. BILlOT, Les Saintes Chapelles (XIII'-XVI siècles) aproche comparée de fondations dynastiques, "Revue d'Histoire Ecclésiastique de la France", LXXIII (1987), pp. 229-248. La capilla de Montpellier al igual que la de París poseía reliquías de la Vera Cruz y de la Corona de Espinas.

${ }^{116}$ En la Corona de Aragón, el proyecto de construir una capilla de reliquias anexa al palacio real de Barcelona por parte de Martín el Humano está totalmente en esa línea. Sobre esta fundación real: M.D. MATEU IBARS, "Bona mobilia et immobilia" del monasterio de los Celestinos y la capilla del Palacio Real Mayor de Barcelona, "Documenta et Scripta", Barcelona, 1993, pp. 89 y ss.
} 


\section{SUMMARY}

The old Moorish Zuda of Lleida was converted into a Christian Royal Palace after the surrender of the town in the year 1149. The structure of the building, which we can still admire today, was shaped during the whole of the XIII century and falls into the Philippe Auguste typology. In a later rennovation (during the reign of Jaime II) the royal chapel -one of the most interesting features of the fortress- was built and, during the XIV century the Tower of the Jews. In this study starting from documental data, old surveyings, and descriptions fron the XVIII century, the process of restrocturing of the building is analized in an attempt to reconstrect the history of the monument which was adequately preserved until 1810. The Palace was destroyed by two explosion in the years 1810 and 1936. 


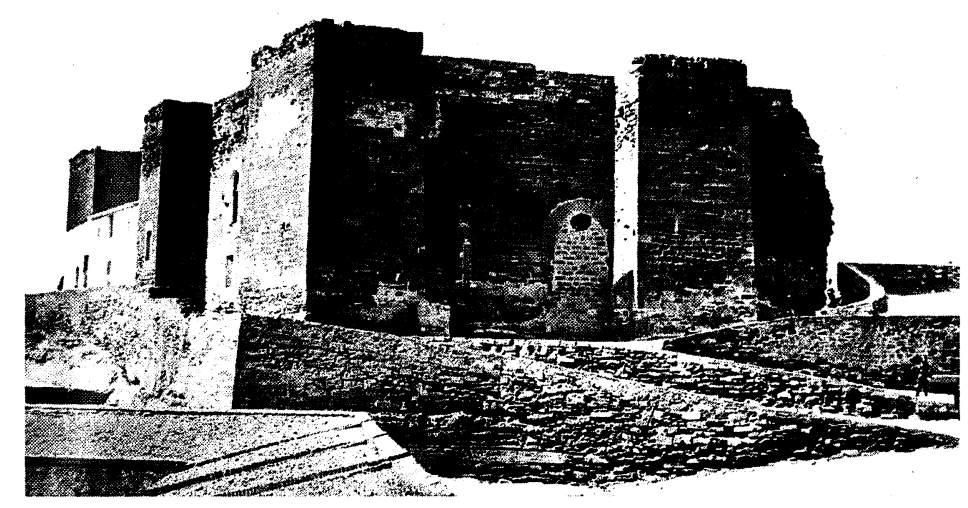

Fig. 3. Vista general exterior (Fotografías anteriores a 1915?). 


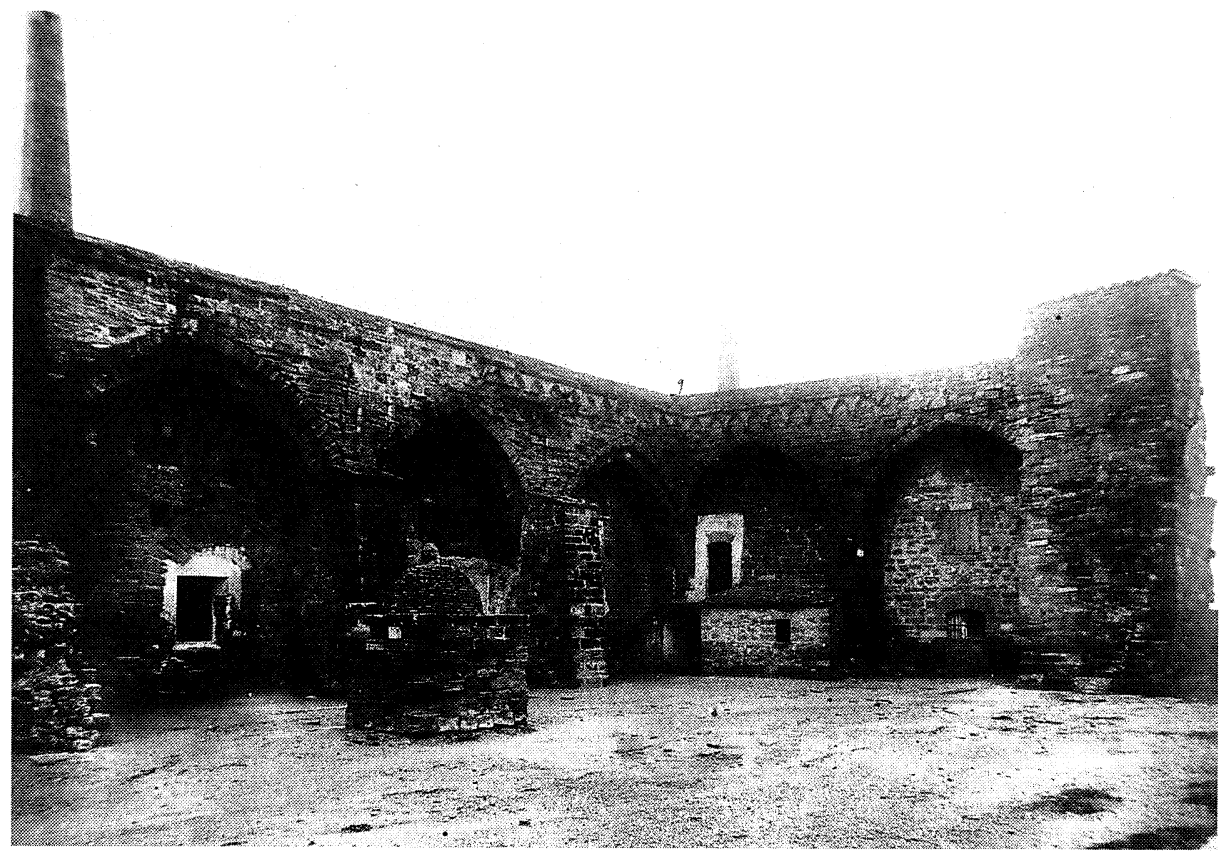

Fig. 4. Vista interior del patio. Angulo suroeste (Fotografía anterior a 1915?). 


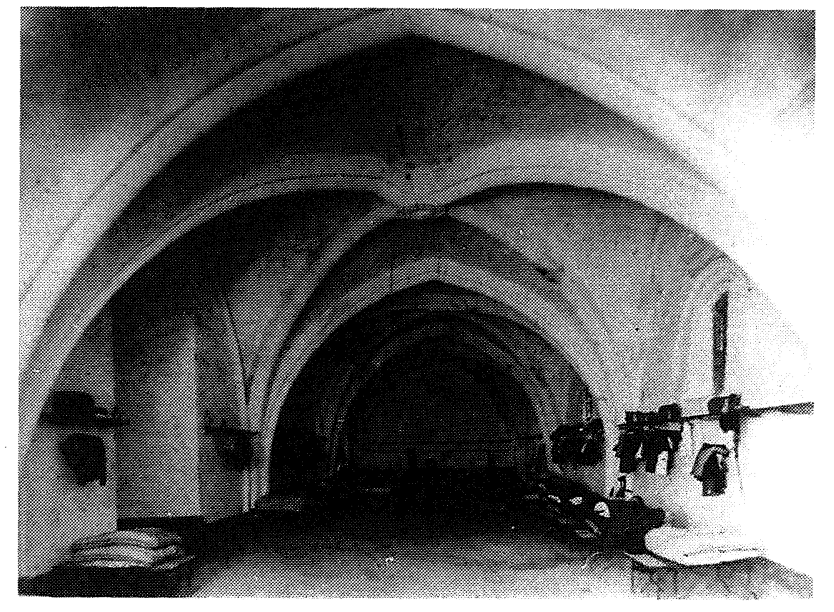

Fig. 5. Interior del ala sur del castillo. Detalle de las bóvedas góticas (Fotografía anterior a 1915?). 


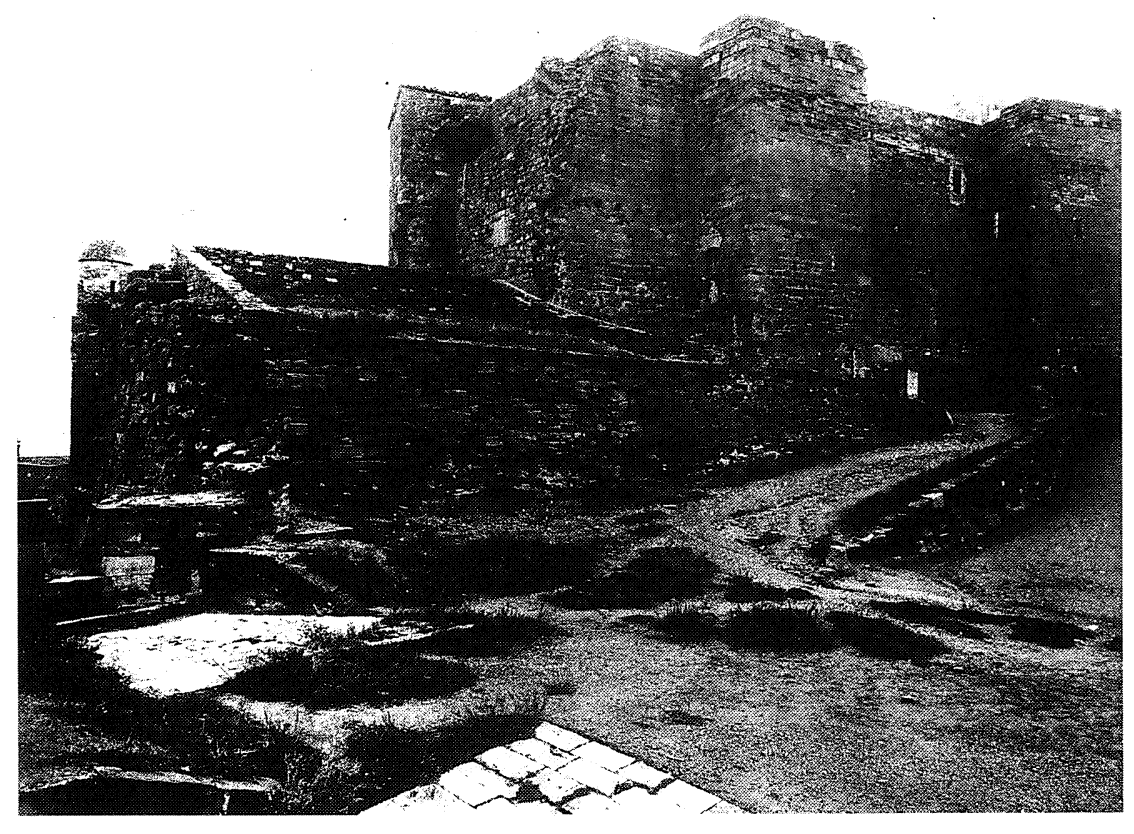

Fig. 6. Exterior del castillo. Sector occidental (Fotografía anterior a 1915?). 


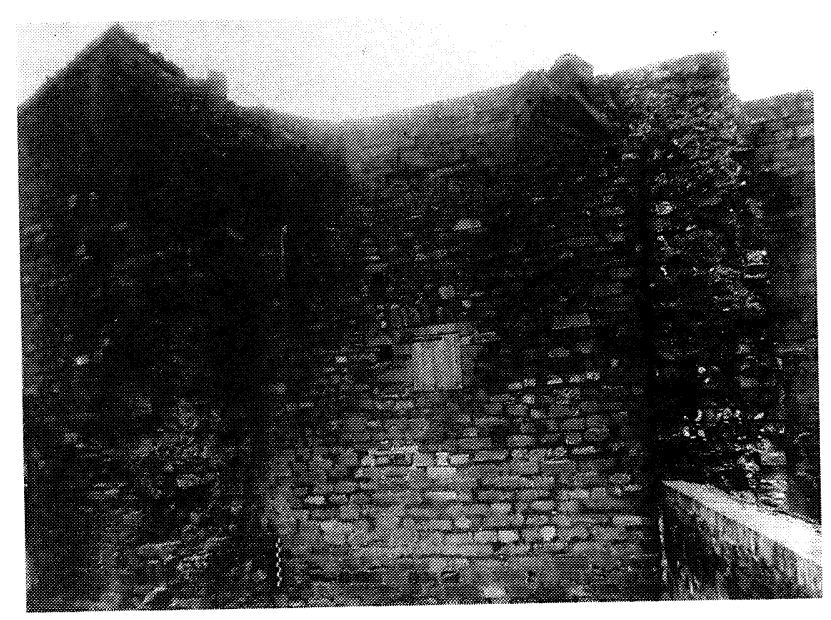

Fig. 7. Restos de la capilla. Detalle de las trompas del cimborrio (Fotografía anterior a 1915?). 


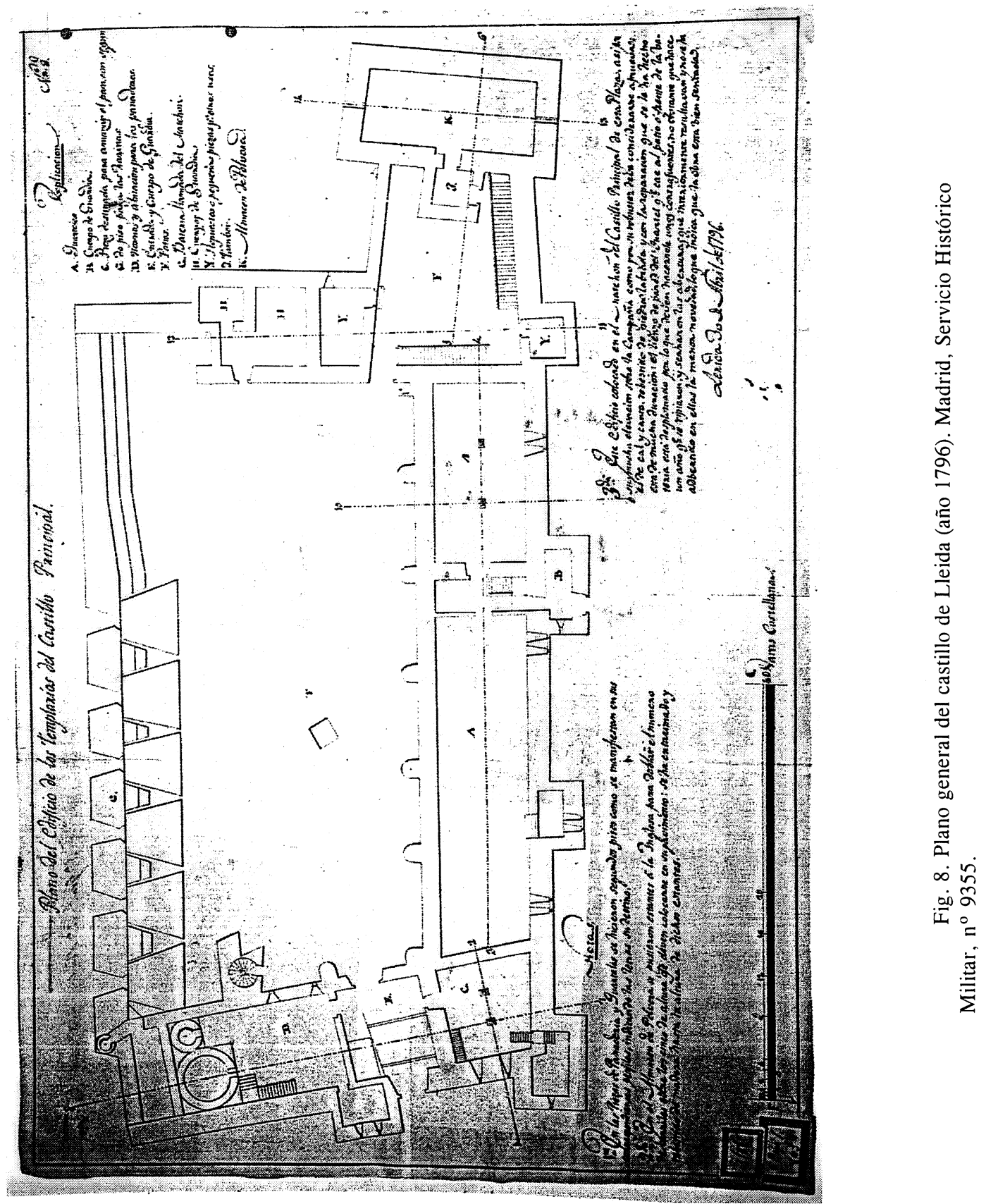




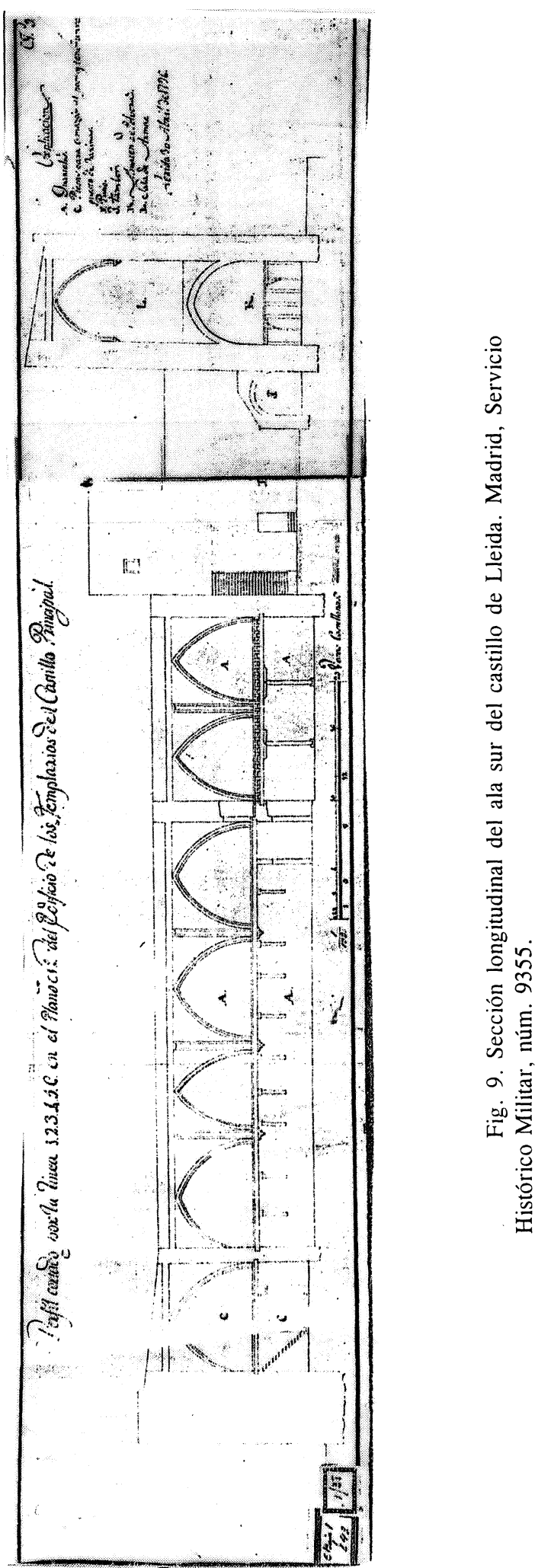




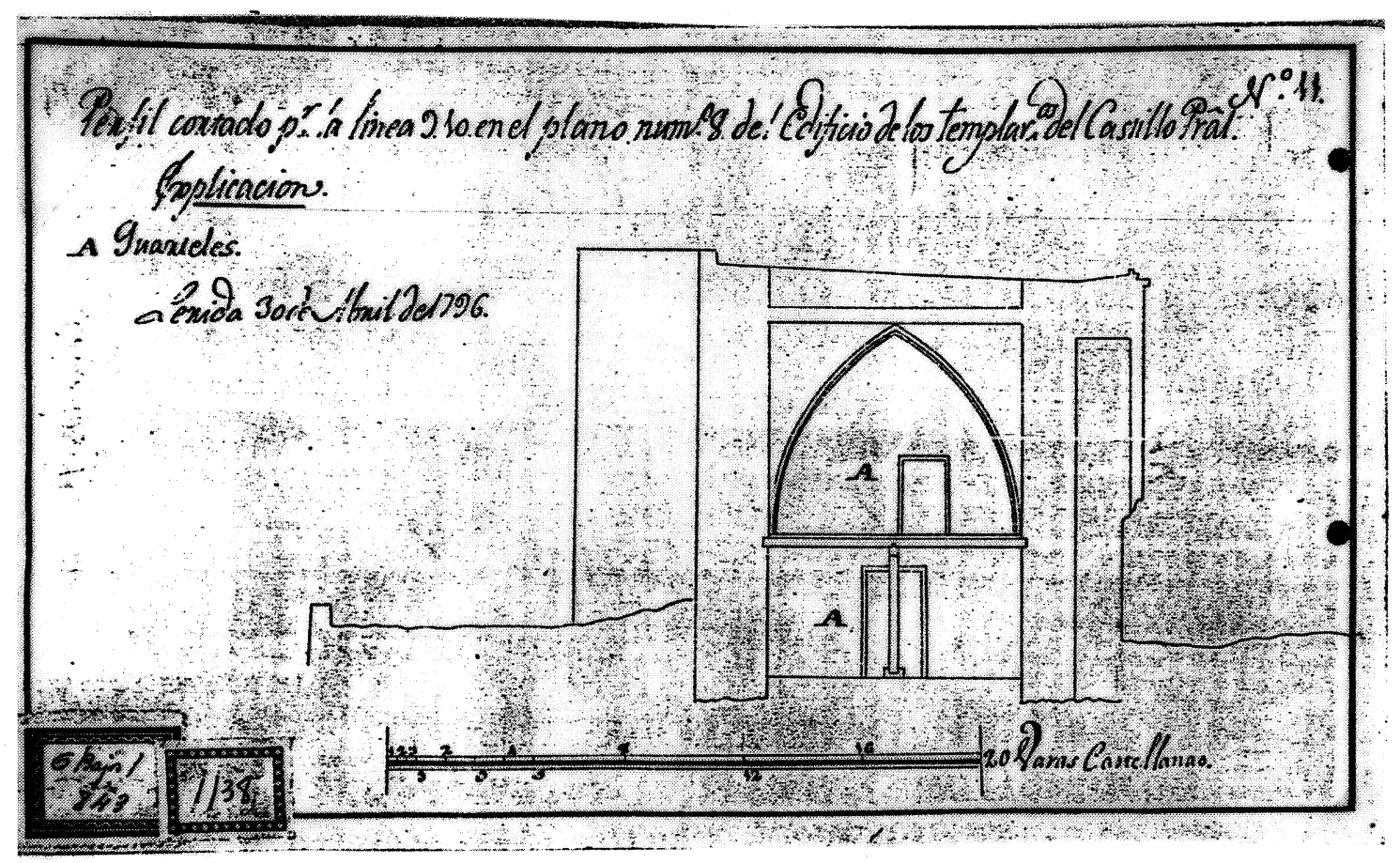

Fig. 10. Sección transversal del ala sur del castillo de Lleida (año 1796). Madrid, Servicio Histórico Militar, núm. 9355. 


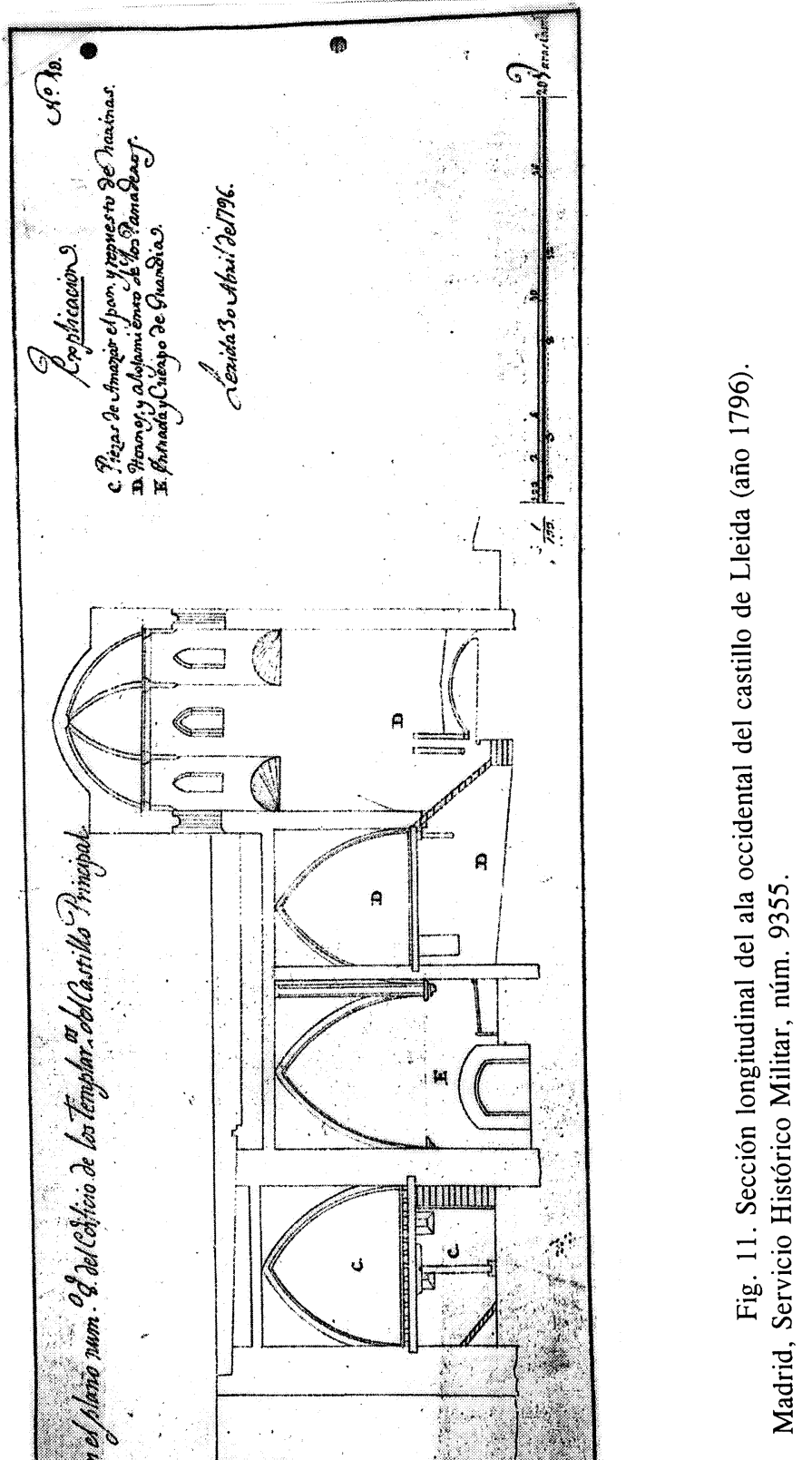




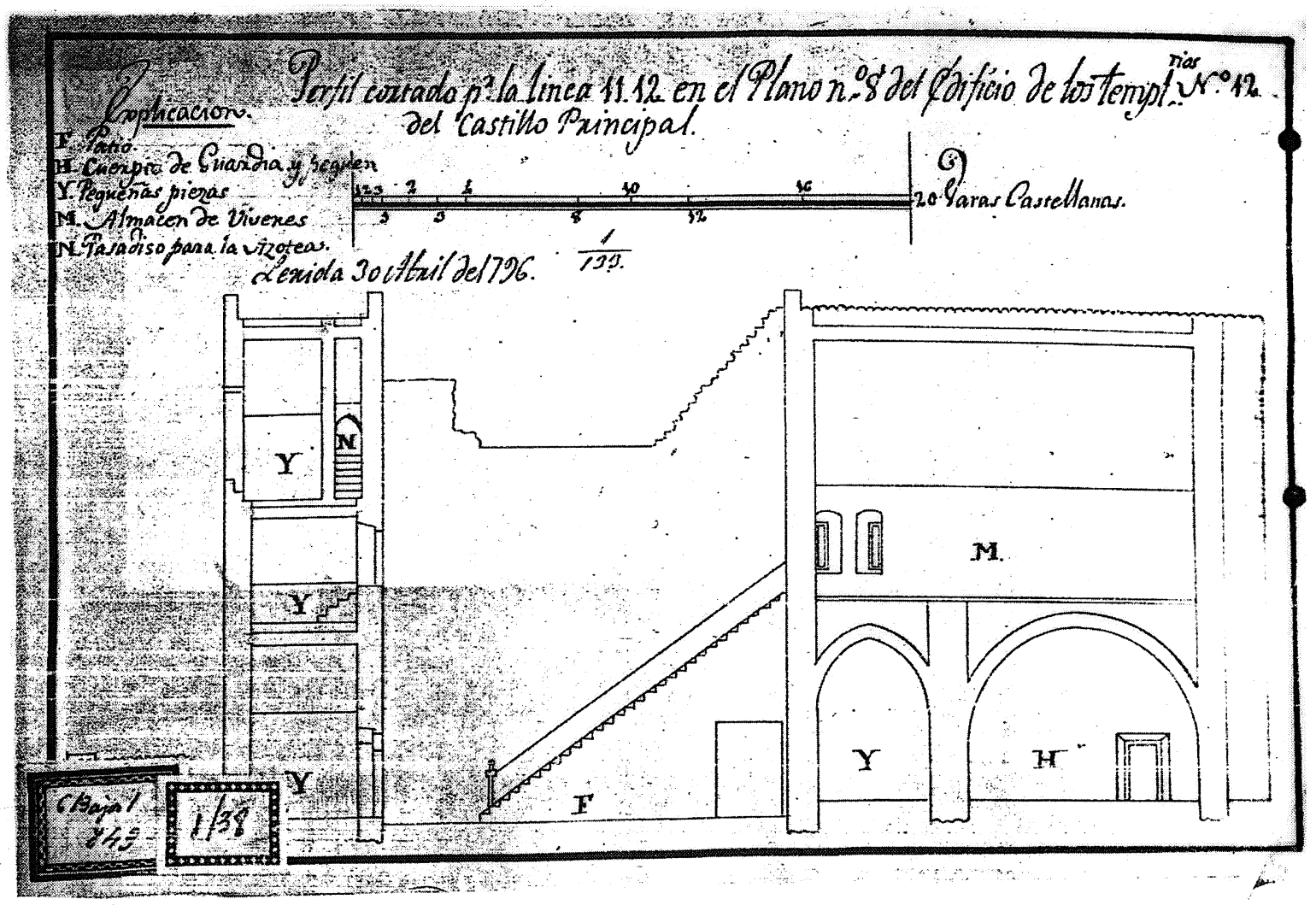

Fig. 12. Sección del sector oriental del castillo de Lleida (año 1796). Madrid, Servicio Histórico Militar, núm. 9355. 


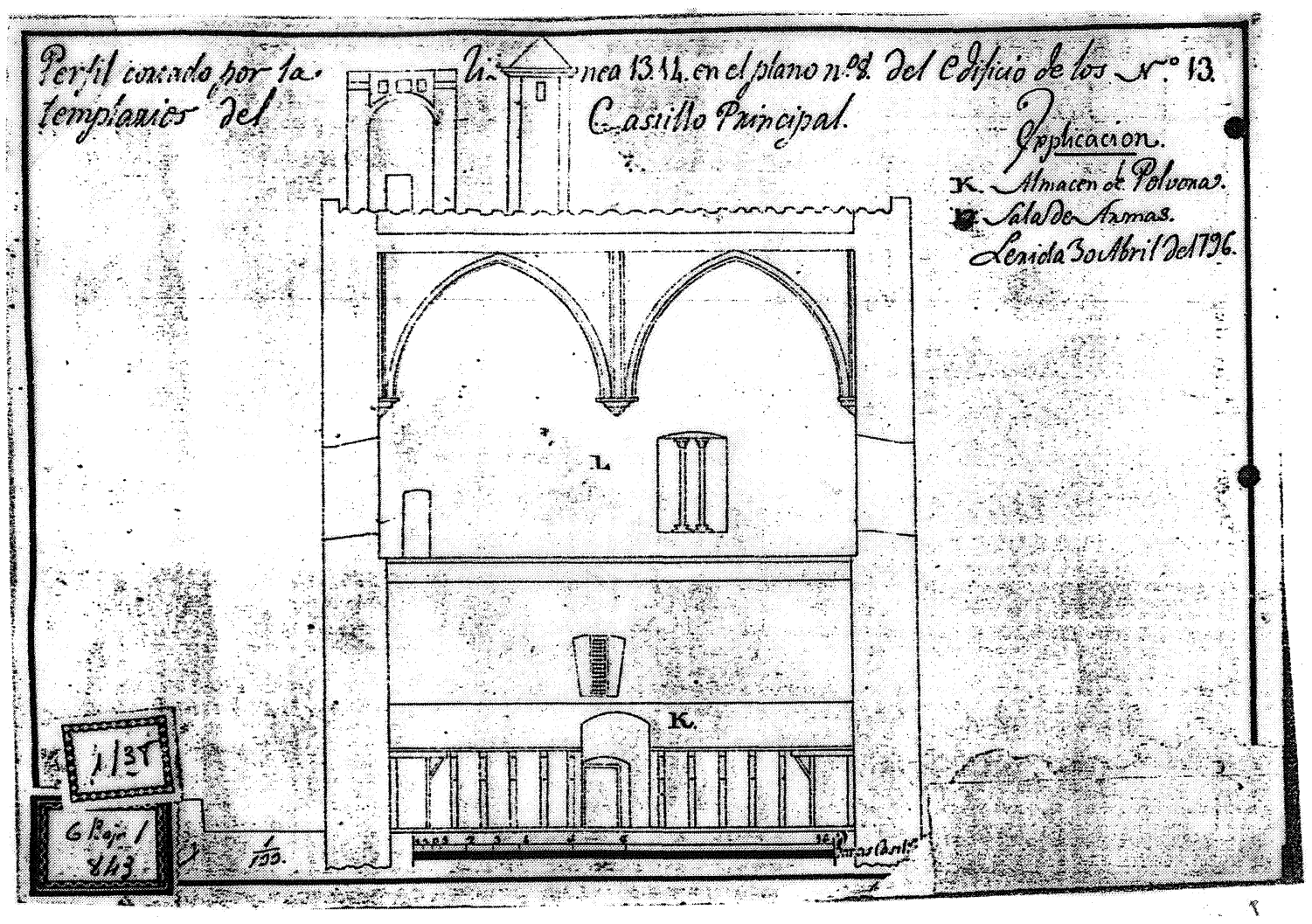

Fig. 13. Sección longitudinal de la Torre dels Jueus, sector oriental del castillo de Lleida (año 1796). Madrid, Servicio Histórico Militar, núm. 9355. 


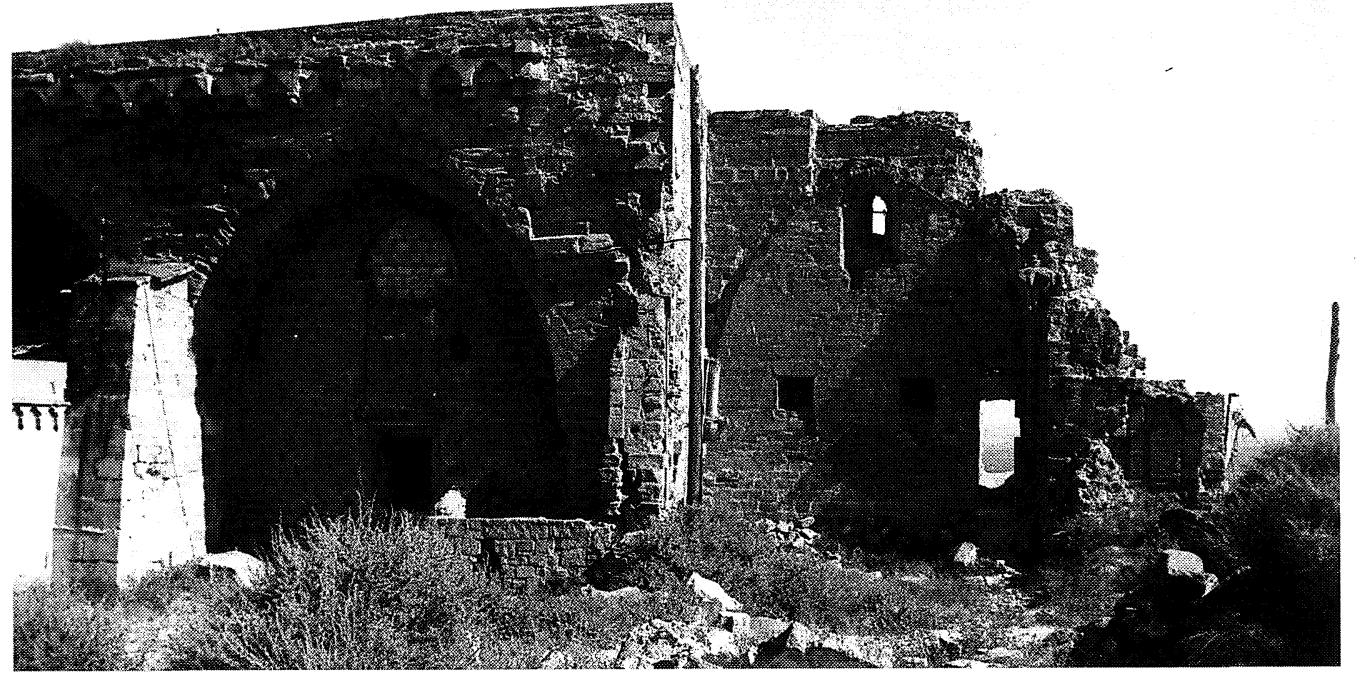

Fig. 14. Estado actual del ángulo suroeste del castillo de Lleida. 


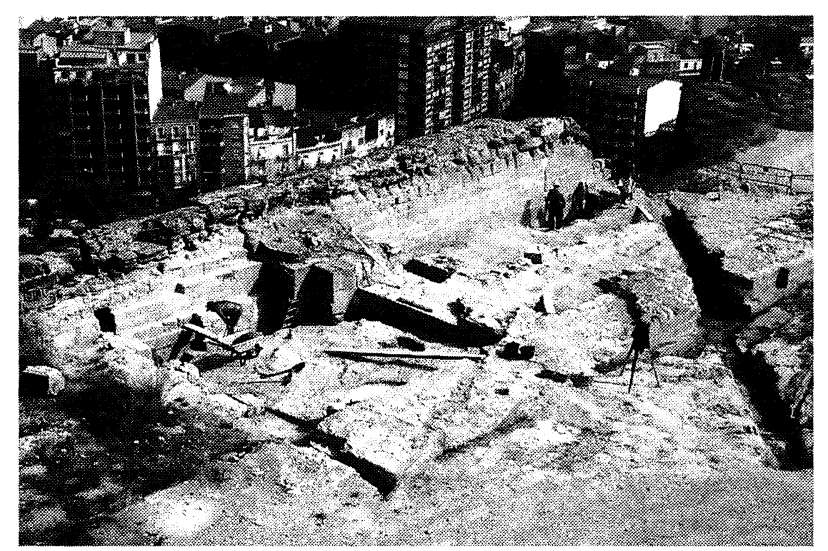

Fig. 15. Vista general de las excavaciones de 1992. Sector norte del castillo real de Lleida. 


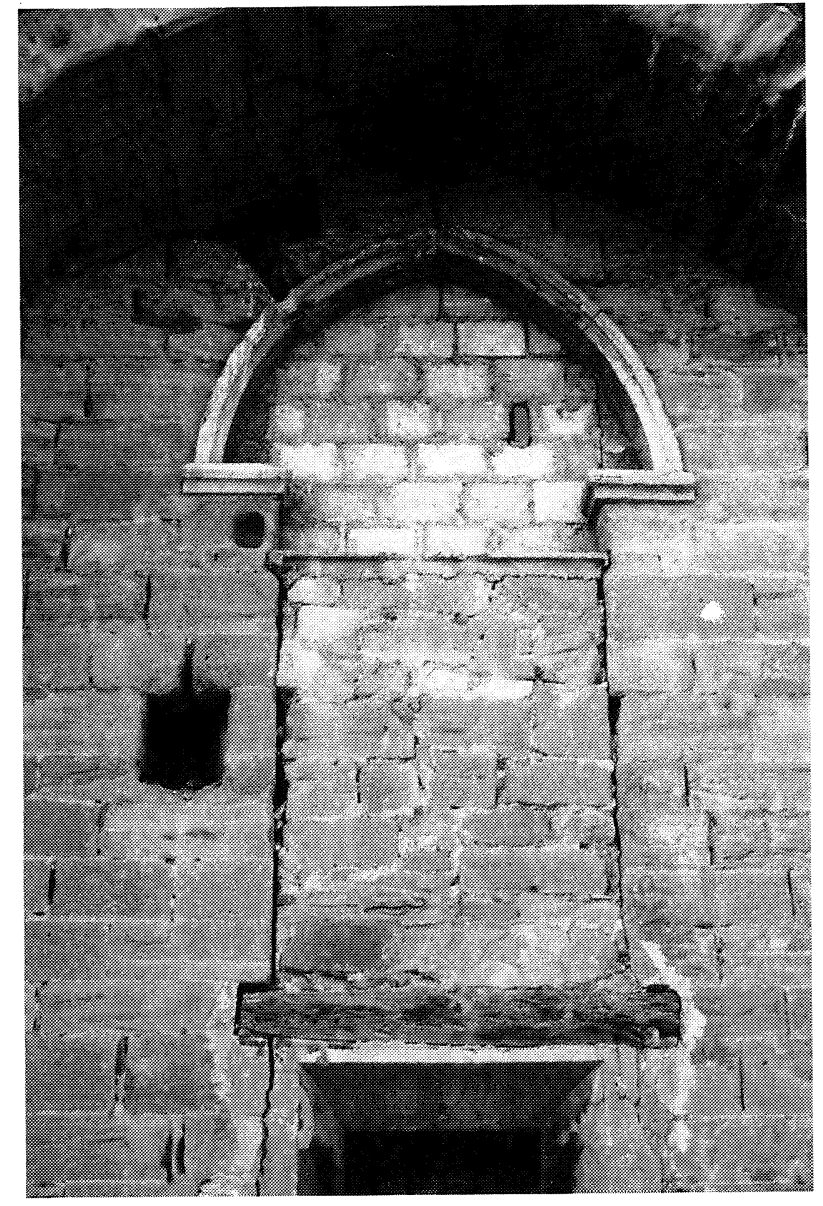

Fig. 16. Detalle de una ventana. Área sur del castillo de Lleida. 


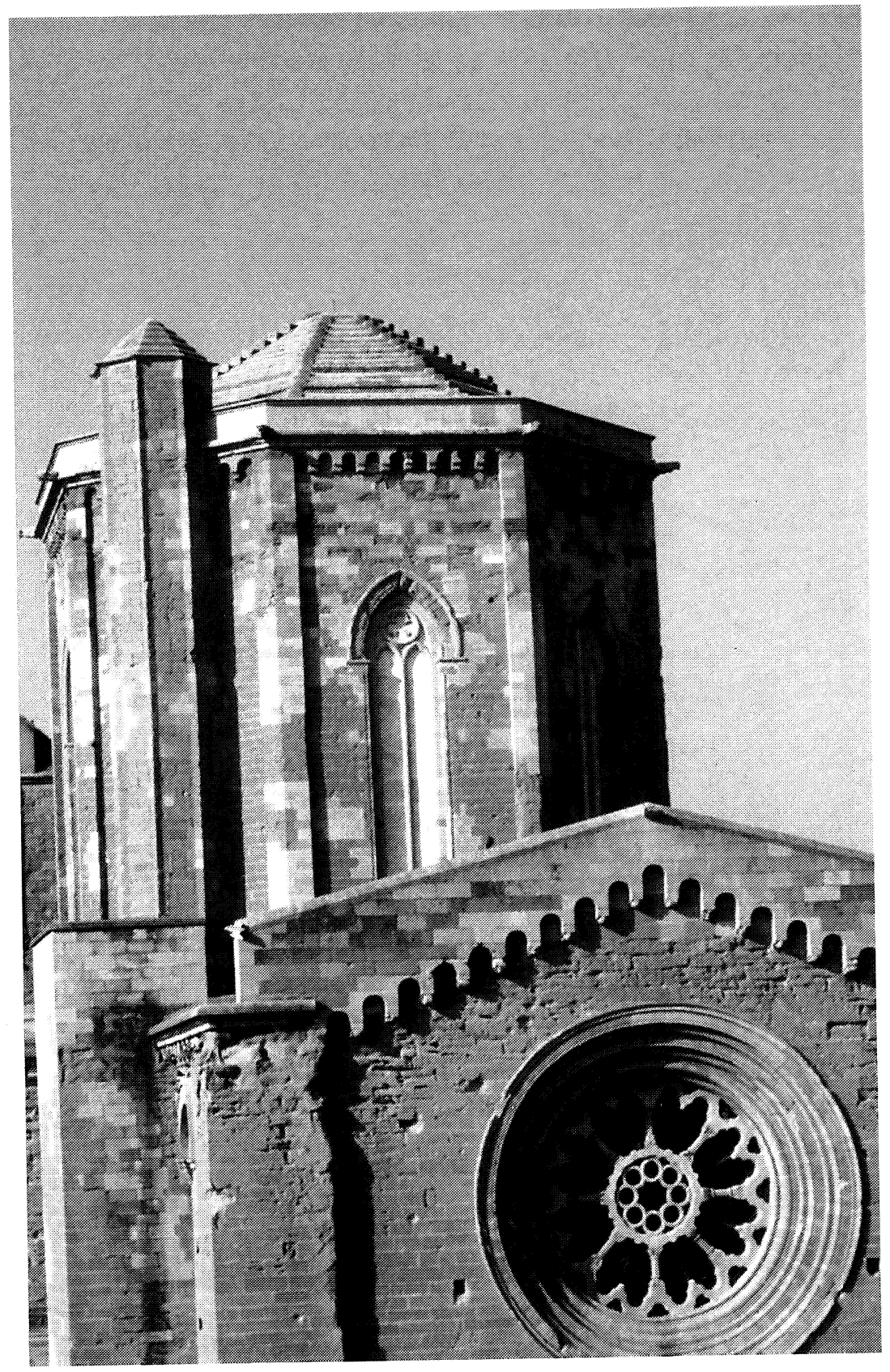

Fig. 18. Exterior del cimborrio de la catedral románica de Lleida. 


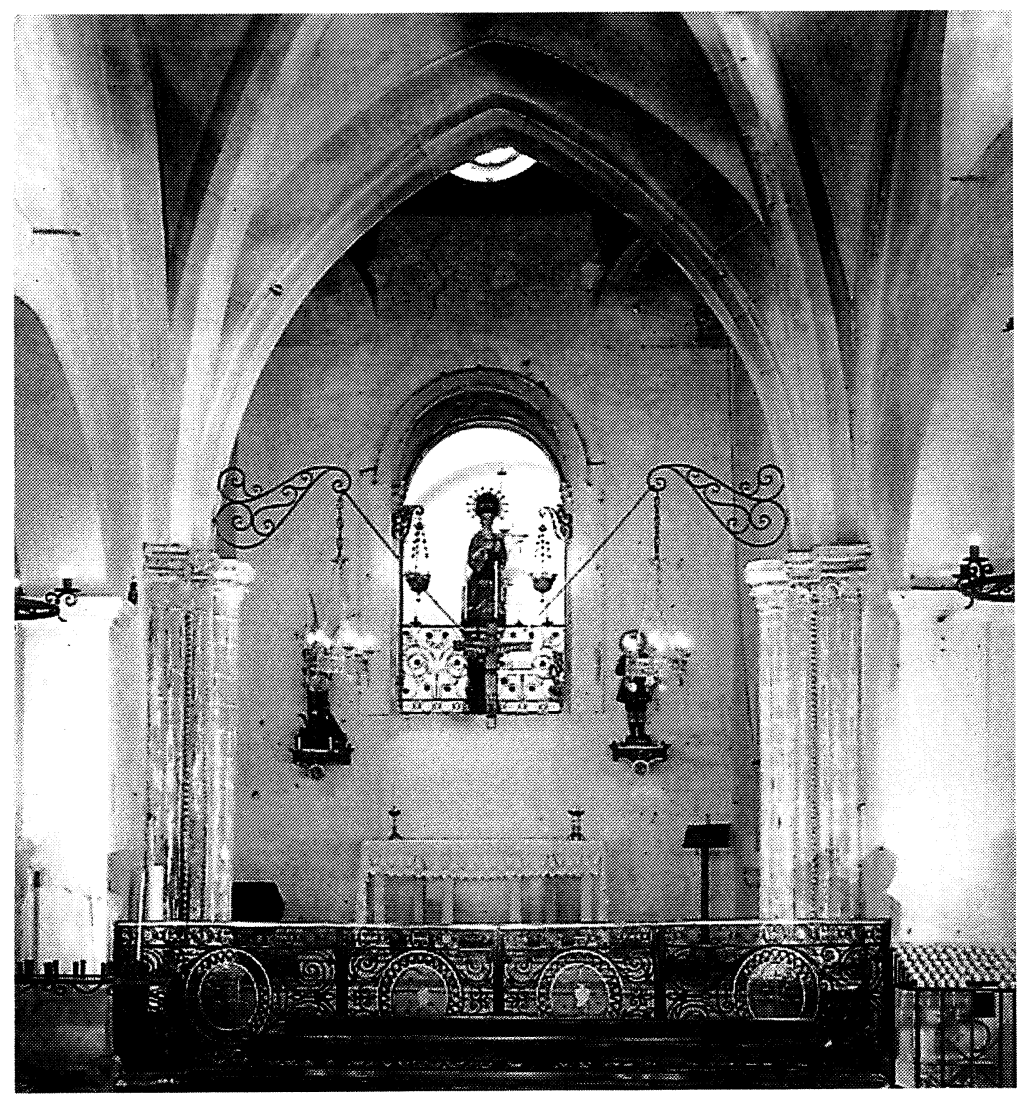

Fig. 21. Interior de la capilla del Castellvell de Solsona. 